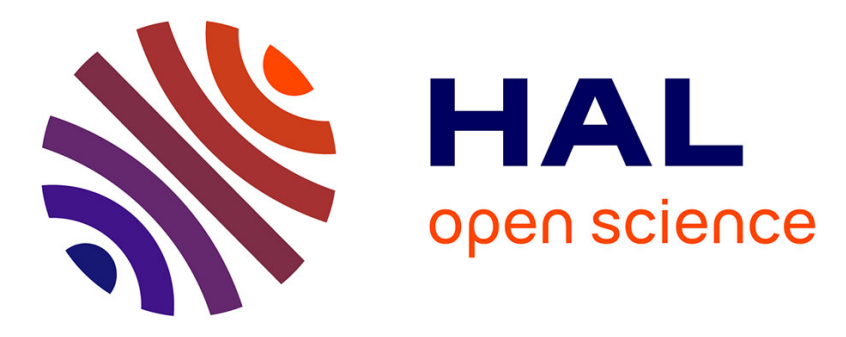

\title{
On the R\&D Landscape Evolution in Catalytic Upgrading of Biomass
}

\author{
Atif Emre Demet, Nathalie Tanchoux, Gabriele Centi, Rita de Luca, Siglinda \\ Perathoner, Francesco Di Renzo, Walter Vermeiren
}

\section{To cite this version:}

Atif Emre Demet, Nathalie Tanchoux, Gabriele Centi, Rita de Luca, Siglinda Perathoner, et al.. On the R\&D Landscape Evolution in Catalytic Upgrading of Biomass. Stefania Albonetti; Siglinda Perathoner; Elsje Alessandra Quadrelli. Horizons in Sustainable Industrial Chemistry and Catalysis, 178, Elsevier, Chapter 8, 2019, Studies in Surface Science and Catalysis, 9780444641274. hal01967432

\section{HAL Id: hal-01967432 \\ https://hal.science/hal-01967432}

Submitted on 6 Nov 2019

HAL is a multi-disciplinary open access archive for the deposit and dissemination of scientific research documents, whether they are published or not. The documents may come from teaching and research institutions in France or abroad, or from public or private research centers.
L'archive ouverte pluridisciplinaire HAL, est destinée au dépôt et à la diffusion de documents scientifiques de niveau recherche, publiés ou non, émanant des établissements d'enseignement et de recherche français ou étrangers, des laboratoires publics ou privés. 


\section{AUTHOR QUERY FORM}

\begin{tabular}{|c|c|c|}
\hline 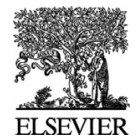 & $\begin{array}{l}\text { Book: Studies in Surface Science and } \\
\text { Catalysis } \\
\text { Chapter Number: } 08\end{array}$ & $\begin{array}{l}\text { Please e-mail your responses and any corrections to: } \\
\text { E-mail: omer.m@elsevier.com }\end{array}$ \\
\hline
\end{tabular}

Dear Author,

Please check your proof carefully and mark all corrections at the appropriate place in the proof (e.g., by using onscreen annotation in the PDF file) or compile them in a separate list. Note: if you opt to annotate the file with software other than Adobe Reader then please also highlight the appropriate place in the PDF file. To ensure fast publication of your paper please return your corrections within 48 hours.

For correction or revision of any artwork, please consult http://www.elsevier.com/artworkinstructions.

We were unable to process your file(s) fully electronically and have proceeded by

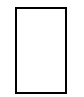

Scanning (parts of) your article

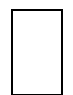

Rekeying (parts of) your article

Scanning the artwork

Any queries or remarks that have arisen during the processing of your manuscript are listed below and highlighted by flags in the proof. Click on the ' $\underline{Q}$ ' link to go to the location in the proof.

\begin{tabular}{|c|c|}
\hline $\begin{array}{l}\text { Location in } \\
\text { Chapter }\end{array}$ & $\begin{array}{l}\text { Query / Remark: click on the Q link to go } \\
\text { Please insert your reply or correction at the corresponding line in the proof }\end{array}$ \\
\hline$\underline{\text { Q1 }}$ & $\begin{array}{l}\text { Figures will appear in } \mathrm{B} / \mathrm{W} \text { in the print version. Please modify references to color in the caption to } \\
\text { match with the } \mathrm{B} / \mathrm{W} \text { print version. }\end{array}$ \\
\hline$\underline{\mathbf{Q 2}}$ & $\begin{array}{l}\text { Figures will appear in } \mathrm{B} / \mathrm{W} \text { in the print version. Please modify references to color in the caption to } \\
\text { match with the } \mathrm{B} / \mathrm{W} \text { print version. }\end{array}$ \\
\hline$\underline{\text { Q3 }}$ & $\begin{array}{l}\text { Figures will appear in } \mathrm{B} / \mathrm{W} \text { in the print version. Please modify references to color in the caption to } \\
\text { match with the } \mathrm{B} / \mathrm{W} \text { print version. }\end{array}$ \\
\hline$\underline{\text { Q4 }}$ & $\begin{array}{l}\text { Please check whether the suggested running head "On the R\&D Landscape Evolution" is } \\
\text { appropriate for this chapter. }\end{array}$ \\
\hline$\underline{\text { Q5 }}$ & Chapter title does not match with the TOC. Please check. \\
\hline Q6 & Please provide the affiliations in English version. \\
\hline
\end{tabular}




\begin{tabular}{|c|c|}
\hline$\underline{\text { Q7 }}$ & $\begin{array}{l}\text { In the sentence that begins "These consituents of first-generation biofuels are in competition..." } \\
\text { refers to "domesticated animals. Do you mean livestock? }\end{array}$ \\
\hline$\underline{\text { Q8 }}$ & $\begin{array}{l}\text { In the sentence that starts, "Each patent family..." This sentence is difficult to edit. And the very } \\
\text { same sentence appears again on page } 8 \text {. }\end{array}$ \\
\hline$\underline{\text { Q9 }}$ & $\begin{array}{l}\text { The sentence, "Herein, PL documents correspond to patent families which are represented by the } \\
\text { representative patent of the family," is a similar sentence I flagged on page 7. Difficult to edit } \\
\text { because I'm not sure of the meaning. }\end{array}$ \\
\hline$\underline{\text { Q10 }}$ & $\begin{array}{l}\text { In the paragraph that starts "Eleven of the top } 20 \text { all-patent countries..." is a duplicate paragraph } \\
\text { from page } 9 \text {, only the information is slightly different. In the paragraph on page } 9 \text {, between Fig. } 8.1 \\
\text { and } 8.2 \text {, claims that " } 13 \text { of the top } 20 \ldots \text { ".. }\end{array}$ \\
\hline Q11 & $\begin{array}{l}\text { In the sentence that begins with "The color-ranking was applied to each column..." and the next } \\
\text { two sentences reference color. I am pointing this out per the guideline requests. }\end{array}$ \\
\hline$\underline{\mathrm{Q} 12}$ & $\begin{array}{l}\text { Figures will appear in } \mathrm{B} / \mathrm{W} \text { in the print version. Please modify references to color in the text to } \\
\text { match with the } \mathrm{B} / \mathrm{W} \text { print version. }\end{array}$ \\
\hline$\underline{\text { Q13 }}$ & $\begin{array}{l}\text { In the sentence that begins, "Their white-colored cells over the previous decade..." has reference to } \\
\text { color, both white and reddish, hereby noted per your request. }\end{array}$ \\
\hline Q14 & $\begin{array}{l}\text { In the sentence that begins, "These promising compounds have a negligible number of records..." } \\
\text { contains references to color. }\end{array}$ \\
\hline$\underline{\mathrm{Q} 15}$ & $\begin{array}{l}\text { Table will appear in } \mathrm{B} / \mathrm{W} \text { in the print version. Please modify references to color in the Table to } \\
\text { match with the } \mathrm{B} / \mathrm{W} \text { print version. }\end{array}$ \\
\hline \multirow[t]{2}{*}{$\underline{\text { Q16 }}$} & $\begin{array}{l}\text { Some portions of the texts are losing their readability while sizing the image as per text area. Could } \\
\text { you please arrange to provide revised figure or shall we proceed as it is. Please check and advice. }\end{array}$ \\
\hline & $\begin{array}{l}\text { Please check this box or indicate your approval if } \\
\text { you have no corrections to make to the PDF file }\end{array}$ \\
\hline
\end{tabular}

Thank you for your assistance. 


\section{S E C T I O N 2}

\section{BIO-BASED PROCESSES AND BEYOND}




\section{H A P T E R}

C0040

\section{On the R\&D Landscape Evolution}

\section{in Catalytic Upgrading of Biomass}

Attf Emre Demet ${ }^{*, \dagger,+}$, Nathalie Tanchoux* Gabriele Centi ${ }^{\S}$, Rita De Luca ${ }^{\dagger}$, Siglinda Perathoner", Francesco di Renzo*, Walter Vermeiren ${ }^{\dagger}$

*Institut Charles Gerhardt, UMR 5253 UM-CNRS-ENSCM, Montpellier, France ${ }^{\dagger}$ Total Research and Technology Feluy, Zone Industrielle Feluy C, Seneffe, Belgium ${ }^{\ddagger}$ Faceltàdi Ingegneria, Università degli Studi di Messina, Messina, Italy ${ }^{\S}$ MIFT, Università degli Studi di Messina,

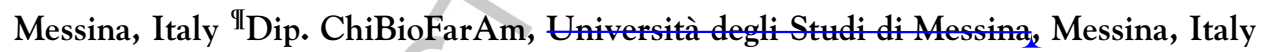

\section{O U T L I N E}

1 Introduction

2 Methodology

3 Overall Trends and Patterns of Evolution

4 Technical Analysis of Catalytic

Conversion of Renewable Biomass
35 Conclusions

5 Acknowledgments

7 References s0010

p0010
Biomass, from vegetable or animal origin, is constituted by organic materials essentially consisting of carbon, hydrogen, and oxygen, along with significant amounts of nitrogen and small amounts of other essential elements required for the metabolism of living material. The energy source of biomass is sunlight and the material source is carbon dioxide, converted through photosynthesis into carbohydrates. Other enzymatic metabolic mechanisms produce fatty acids, amino-acids, proteins, and complex aromatics, which are the basis of lignin 
4

in plants. Plant biomass, which is essentially lignocellulose, stores solar energy and is often used as feed for animals-plants and animals together, forming the food for mankind. Other biomass types, such as wood, are used as construction materials and heat generation. Burning of biomass has always been the most direct way to use its contained energy, although two main constituents of certain biomass types are being converted into fuels to be blended with fossilbased gasoline and diesel. Biofuel production has been incentivized for sustainability reasons to reduce the carbon footprint of human transportation. Sugars (or starch) and triglycerides are the most accessible components for large amounts of energy storage in plants. Simple sugars can readily be fermented into ethanol and triglycerides can be catalytically converted into the corresponding methyl-esters, which can be blended with either gasoline or diesel. These constituents of first-generation biofuels are in competition with resources of food for humans and feed for domesticated animals. The complex nature of biomass energy (lignin, carbohydrates, proteins, etc.) has limited its use to burning for heat and electricity generation. A further development has been to convert wood and food waste, agricultural residues, animal manure, and human sewage into biogas by fermentation into a mixture of methane and carbon dioxide.

p0015 In the last decade a lot of progress has been made in diverting complex biomass to fuel applications. Hereto, lignocellulose is decomposed into its constituents, cellulose, hemicelluloses, and lignin. Cellulose and hemicelluloses can enzymatically be depolymerized, and the obtained simple sugars can be fermented into ethanol. Biotechnology research has flourished enormously and has resulted in plentiful applications to convert sugars into other chemicals (isobutanol, isoprene, isobutylene, farnesene, butanediols, lactic acid, succinic acid, etc.). At the same time, the scientific community and industrial developers have evaluated the potential of nonenzymatic catalysis for biomass conversion. Catalysts have the advantage over enzymes to sustain higher temperature and pressure. On the other hand, they are generally less specific in product formation. Although in the fossil-based petrochemical and chemical industries, $85 \%-90 \%$ of the conversion processes employs catalysts and probably every marketable product has been in contact with a catalyst at least once. Still, most of the biomass-derived products are produced via fermentation or enzymatic pathways. The essential features of catalysis (whether heterogeneous, homogeneous, or enzymatic) is that they accelerate reactions, and according to the implied mechanism, they can do this with selectivity for one desired product.

Science and technology monitoring can be p0020 performed by the following two methods: stateof-the-art search, or innovation watch. The state-of-the-art search mainly focuses on the prior art of the related technology (one knows what one is looking for). It is a useful type of search method to determine the patentability of a product as part of a specific patent application or to prepare for new research projects (requiring background information). However, innovation watch is typically performed for technology landscape studies to comprehend beyond the state-of-the-art search in order to study the technological evolution of a particular field to identify and detect emerging technologies [1].

In 2015 and 2016, respectively, 2,887,300 and p0025 $3,127,900$ patent applications were filed worldwide. Put another way, for the first time ever, more than 3 million patent applications were filed globally in 2016 in a single year, up $8.3 \%$ from $2015[2,3]$. China, the United States, and Japan are the first three main drivers of global scientific and technological growth. However, it is impressive that China by itself received more applications than the combined total for the United States, EPO, Japan and the Republic of Korea.

Of all the global patent applications filed in p0030 2016, $21.8 \%$ were in chemistry-related fields. 
TABLE 8.1 Published Patent Applications Worldwide by Field of Technology in Chemistry [3]

\begin{tabular}{llllll}
\hline Field of Technology in Chemistry & $\mathbf{2 0 0 5}$ & $\mathbf{2 0 1 0}$ & $\mathbf{2 0 1 5}$ & $\begin{array}{l}\text { Share (\%) } \\
\text { of 2015 }\end{array}$ & $\begin{array}{l}\text { Average Growth (\%) } \\
\text { 2005-2015 }\end{array}$ \\
\hline Food chemistry & 22,391 & 27,659 & 63,150 & 2.5 & 10.9 \\
$\begin{array}{l}\text { Microstructural and } \\
\text { nanotechnology }\end{array}$ & 2145 & 3366 & 4725 & 0.2 & 8.2 \\
Materials, metallurgy & 29,406 & 37,377 & 63,835 & 2.5 & 8.1 \\
Basic materials chemistry & 39,075 & 44,451 & 82,202 & 3.3 & 7.7 \\
Environmental technology & 20,880 & 25,776 & 42,979 & 1.7 & 7.5 \\
Chemical engineering & 33,619 & 36,887 & 60,479 & 2.4 & 6.0 \\
Macromolecular chemistry, & 27,965 & 28,531 & 45,576 & 1.8 & 5.0 \\
polymers & & & & & 4.3 \\
Surface technology, coating & 27,962 & 32,222 & 42,671 & 1.7 & 3.8 \\
Biotechnology & 38,296 & 39,068 & 55,499 & 2.2 & 3.4 \\
Pharmaceuticals & 73,701 & 71,276 & 102,790 & 4.1 & 1.0 \\
Organic fine chemistry & 57,323 & 54,253 & 63,603 & 2.5 & 4.8 \\
Total & 374,768 & 402,876 & 629,524 & 24.9 & \\
\hline
\end{tabular}

Table 8.1 illustrates the published patent applications worldwide by field of technology in chemistry, as adapted from the World Intellectual Property Indicators 2017 [3]. Among them, pharmaceuticals, basic materials chemistry, and organic fine chemistry are the most contributing fields between 2005 and 2015; while food chemistry, microstructural and nanotechnology, materials-metallurgy are the three chemistryrelated fields with the highest average growth rates over a decade. Average growth rate of all chemistry-related fields between 2005 and 2015 is $4.8 \%$.

\section{METHODOLOGY}

p0035

This section provides a detailed explanation of the dataset comprising both patent (PL) and nonpatent literature (NPL) covered under this $R \& D$ landscape study on the catalytic upgrading of biomass. Herein, the technology scope of biomass refers to algal and lignocellulosic biomass resources; whereas catalytic upgrading refers to conversion of the aforementioned biomass resources by various processes using heterogeneous catalytic routes.

Nonpatent literature (NPL) publications were p0040 retrieved from Scopus, which is the largest abstract and citation database of peer-reviewed literature, with more than 69 million core records. Approximately 3 million new items are added to the database each year $[4,5]$. NPL publications addressed in this study consist of articles, reviews, conference proceedings, book chapters, and articles in the press, which are covered in the Scopus database, matched with the search criteria performed within the search fields of title, abstract, and keyword.

Patent literature (PL) publications were p0045 retrieved from the Enhanced Patent Data of Derwent World Patents Index (DWPI). DWPI is the 
6

8. ON THE REDLANDSGAPE EVOLUTIOA

most comprehensive database of enhanced patent information in the world. The database is produced by Derwent Innovation-Clarivate Analytics and it includes data from over 50 worldwide patent authorities covering 72.7 million patent records and 34.7 million patent families [6]. DWPI has been selected as a PL data-source in this study to have a more enhanced and accurate dataset because it offers rewritten patent data by subject experts, which provide speaking titles and abstracts summarizing the novelty of the invention, as well providing unique coding and indexing. The Derwent abstract is generally much richer than the original abstract, which is merely a copy of the first claim. PL publications in this study consist of patent-related records which are covered in the DWPI database and fulfill the criteria performed within the search fields of title, abstract, and independent claims.

p0050 The first step in preparing such an R\&D landscape study is to determine the main objectives and the boundaries of the technology scope. This study was conducted not only to compare the patent literature with the nonpatent literature, which covers the records on upgrading algal and lignocellulosic biomass resources by heterogeneous catalytic routes, but also to understand the overall trends and the technical patterns of evolution in the field. The terminology used in this study covers the technical language used by experts who cross-functionally work in in several technical fields: IP, catalysis, and renewable biomass energy.

p0055 In order to retrieve the relevant technological information from the databases, three levels of combined information were searched:

o0010 1. The feedstock: biomass descriptors;

o0015 2. Conversion routes: heterogeneous catalysts descriptors while excluding homogeneous and enzymatic catalysts as much as possible;

00020 3. Use of product: general applications as fuels, monomers, polymers descriptors; and identified chemical products descriptors.

p0075 Initially, the necessary principal keywords for the creation of search strings (queries) were obtained by screening the related topics by highly cited review publications. The obtained keywords were categorized and segmented into the sets of keywords, like pieces of a puzzle, addressing various technical subgroups such as feedstock, conversion processes, biofuels, and value-added chemicals, type of solid catalysts, etc. Numerous searches were iteratively carried out; the results of each generation of search queries were sampled and systematically reviewed for verification and further evaluation. Hence the spectrum for each set of keywords was enriched by the addition of further key terms of interest, the synonyms and their derivatives generated using truncation operators (such as?, and *). Several tailor-made search strategies were crafted by logically linking the keyword-set of each technical sub-group with the keyword-set of others using Boolean (AND, OR, NOT, AND NOT), and proximity (ADJ/PRE, NEAR, "“") operators. The sample query below corresponds to the set of keywords belonging to the subgroup for biofuels and value-added chemicals. This search query was performed to collect relevant NPL records from the Scopus database, which fulfill the request within the fields of title-abstract-keywords, published in English between 1998 and 2017. Likewise, similar strategies were improved and applied for the creation of PL collection. As a last step, refinement strategies were performed to remove irrelevant results and to decrease noise, particularly excluding fermentation, bacterialand enzyme-related keywords, only within title, in order to obtain a reliable and manageable dataset for PL and NPL collections remaining within the boundaries of the technology scope of this R\&D landscape study.

For the sample query:

( ( ( TITLE-ABS-KEY ( (green OR sustainable OR renewable OR value OR valuable OR platform ) $\mathrm{PRE} / 1$ ( bioplastic OR biomonomer OR biopolymer OR biodiesel OR biogasoline ))) AND ( ( PUBYEAR > 1997 AND PUBYEAR < 2018$))$ ) OR (( TITLE-ABS-KEY ( (green OR sustainable 
OR renewable OR value OR valuable OR platform OR biobased ) PRE/1 ( "building block" ))) AND (( PUBYEAR > 1997 AND PUBYEAR $<2018))$ ) OR (( TITLE-ABS-KEY (( green OR sustainable OR renewable OR value OR valuable OR platform OR biobased ) PRE/1 $($ *fuel* ) )) AND (( PUBYEAR > 1997 AND PUBYEAR < 2018$)))$ ) OR (( TITLE-ABS-KEY ( ethanol OR glycerol OR lactic OR hydroxypropionic OR succinic OR fumaric OR malic OR aspartic OR butyrolactone OR itaconic OR levulinic OR glutamic OR xylitol OR arabitol OR arabinitol OR valerolactone OR gvl OR glucaric OR sorbitol OR fdca OR hmf OR *furan* OR *furfural* )) AND $(($ PUBYEAR > 1997 AND PUBYEAR < 2018$)))$ )) AND ( LIMIT-TO ( LANGUAGE , "English" ))

the final dataset consists of an NPL collection of 7866 nonpatent documents and a PL collection of 6485 patent family documents (November 2017). A patent family is the set of interrelated patent applications filed in one or more countries to protect the same or a similar invention by a common inventor and linked by a common priority (or priorities) [7]. The 6485 documents of simple or extended patent families in this study cover 15,978 patent records. Each patent family is represented by the representative patent of the family.

p0090 The dataset (so-called "the entire collection") consist of 14,351 of (6485) PL and (7866) NPL documents, retrieved from DWPI and Scopus, and exported onto the Questel Intellixir analytics platform, where the documents were further organized and indexed for a deeper analysis of the merged PL and NPL dataset. The Intellixir analytics platform is an analysis tool in which data originating from different sources can be loaded and blended, normalized, and categorized according to custom fields. Complex value strings were created to generate specified custom fields in various technical fields for further analysis. A custom field corresponds to segmentation and so its values correspond to sub-segments, the aim being to categorize the study content with the competence of experts, helped by Intellixir's vocabulary statistics or other glossaries or thesauri [1]. Value strings were mainly created within the fields of titleabstract-descriptors and title-abstract-claims for NPL and PL documents, respectively. Custom field value searches were iteratively carried out; the results of each generation of search queries were sampled and systematically reviewed for verification and further evaluation.

It should be emphasized that the categoriza- p0095 tion of documents using complex queries is only based on text-mining semantic retrieval and that neither manual interpretation nor corrections have been applied. The assumption is that the document titles and abstracts or claims are sufficiently explicit to underpin the added value of the document and minimize noise (which would be very significant when using the introductions of scientific publications or the prior art description of patents, where reference is made to the general framework of the discussed topic).

\section{OVERALL TRENDS AND PATTERNS OF EVOLUTION}

This section provides detailed information p0100 about overall trends of the patent and nonpatent documents covered under the R\&D landscape of catalytic upgrading of biomass over the last two decades.

Because patent rights generally last for p0105 20 years from the priority date the application was filed, the time coverage for this landscape study was determined as 20 years. The complete set of information by years through this period allows evaluating trends in the PL of a related field of technologies. Similarly, the publication years of NPL documents also cover the timeline between 1998 and 2017, thus allowing the comparison of the PL and NPL collections. Fig. 8.1 illustrates the temporal distribution of PL and NPL publications included in the dataset, which 
8

8. ON THE R L LANDSCAPE EVOLUTION

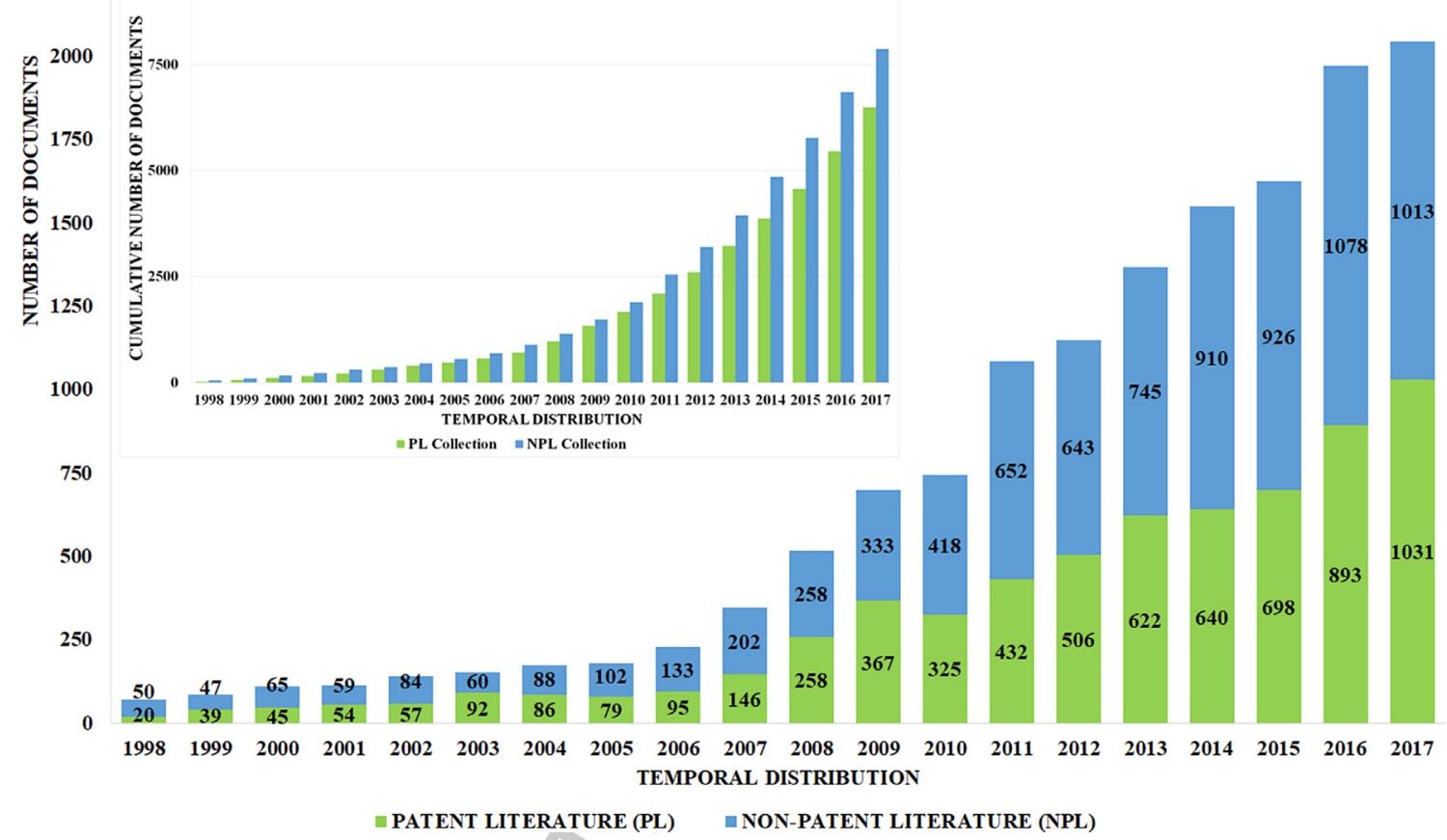

FIG. 8.1 Temporal distribution of the PL (green) and NPL (blue) publications in the R\&D landscape study.

consists of 14,351 documents. Herein, PL documents correspond to patent families which are represented by the representative patent of the family. To be able to make a comparison with the NPL collection, the temporal distribution for PL documents was based on the first publication date instead of the priority date due to the delay between the filing of patents and the publication by patent offices, usually taking place 18 months later.

p0110 This temporal distribution demonstrates that the increase in the number of both PL and NPL documents, and the interest in catalytic upgrading of biomass have been continuously growing over the last two decades. There exist two distinct phases: a first phase between 1998 and 2007, (called "the previous decade") and a second phase between 2008 and 2017, (called "the last decade"). The dataset of both PL and NPL for 2017 does not contain records from December 2017.
The increase in the number of PL and NPL p0115 documents on the second phase of this timeline is attention-drawing. Of the number of PL and NPL documents in this R\&D landscape study, the average growth rate over the last decade corresponds to $14.8 \%$, which is more than threefold the average growth rate of patent applications published worldwide in all chemistry related fields (see Table 8.1). Moreover, the growth rate of the number of documents in the PL collection $(16.6 \%)$ is very similar to the growth rate of the number of documents in the NPL collection $(16.4 \%)$. Despite this tiny difference, it can be expected that PL would contribute more documents than NPL to the entire collection in this technology scope. Indeed, the trend shows the primacy of NPL over PL in the contribution to the entire collection between 2004 and 2016 but eventually, in 2017, PL provided more documents than NPL to the entire collection. 


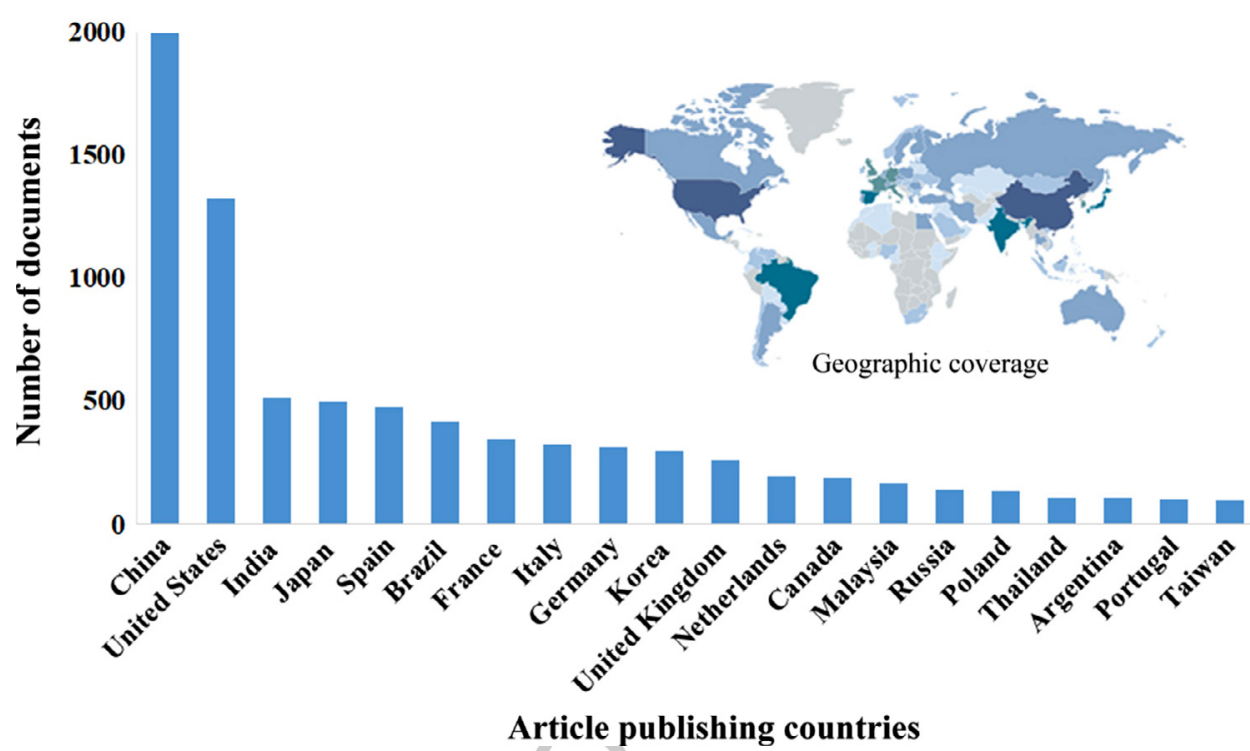

f0015 FIG. 8.2 The top 20 NPL countries and geographic coverage in the R\&D landscape study.

Although it is recognized that the 2017 statistics collected are incomplete, as the dataset does not contain records of the entire year, the data suggest that 2017 is a trend-twist year in this R\&D landscape. The 2017 data compared to the fraction of PL (45\%) and NPL (55\%) documents in the entire collection (the total number of PL and collections by years can be seen in the inset of Fig. 8.1), indicate an evolution in favor of patent literature. It is also expected that the growth of the entire collection will continue in the coming years. So far, there is no sign of reducing interest in catalytic conversion of biomass.

p0120 Fig. 8.2 shows the ranking of top $20 \mathrm{NPL}$ countries and overall geographic coverage of 7866 nonpatent documents in this $R \& D$ landscape study. NPL documents were originated from 97 countries. China (20.6\%) and the United States $(13.6 \%)$ are the main contributing countries to the NPL collection. Thirteen of top 20 countries are in high-income economies; six are in upper middle-income countries (China, Brazil, Malaysia, Russia, Thailand and Argentina). The only country among the lower middle-income economies is India, ranked third, with a $5.3 \%$ of the share. The remaining $17.4 \%$ NPL documents were produced by the rest of the world.

Fig. 8.3 represents the ranking of top 20 PL p0125 countries and the corresponding fraction of patent extension. The ranking is based on the geographical indications of all members of patent families in the PL collection of this landscape study: as mentioned earlier, the 6485 simple or extended patent family documents which cover 15,978 patent records. 6485 PL documents were first filed and identified by the priority number in 46 originating countries; the invention protection of 9494 PL documents has been expanded in 39 extended countries. Further details (number of patent applications, share, income level) of the top 20 patent-originating and extended countries are reported in Table 8.2.

Eleven of the top 20 all-patent countries are in p0130 high-income economies, five are in upper middle-income countries (China, Brazil, Malaysia, Russia, Thailand and Argentina) and two are in the lower middle-income economies 


\section{B978-0-444-64127-4.00008-2, 00008}

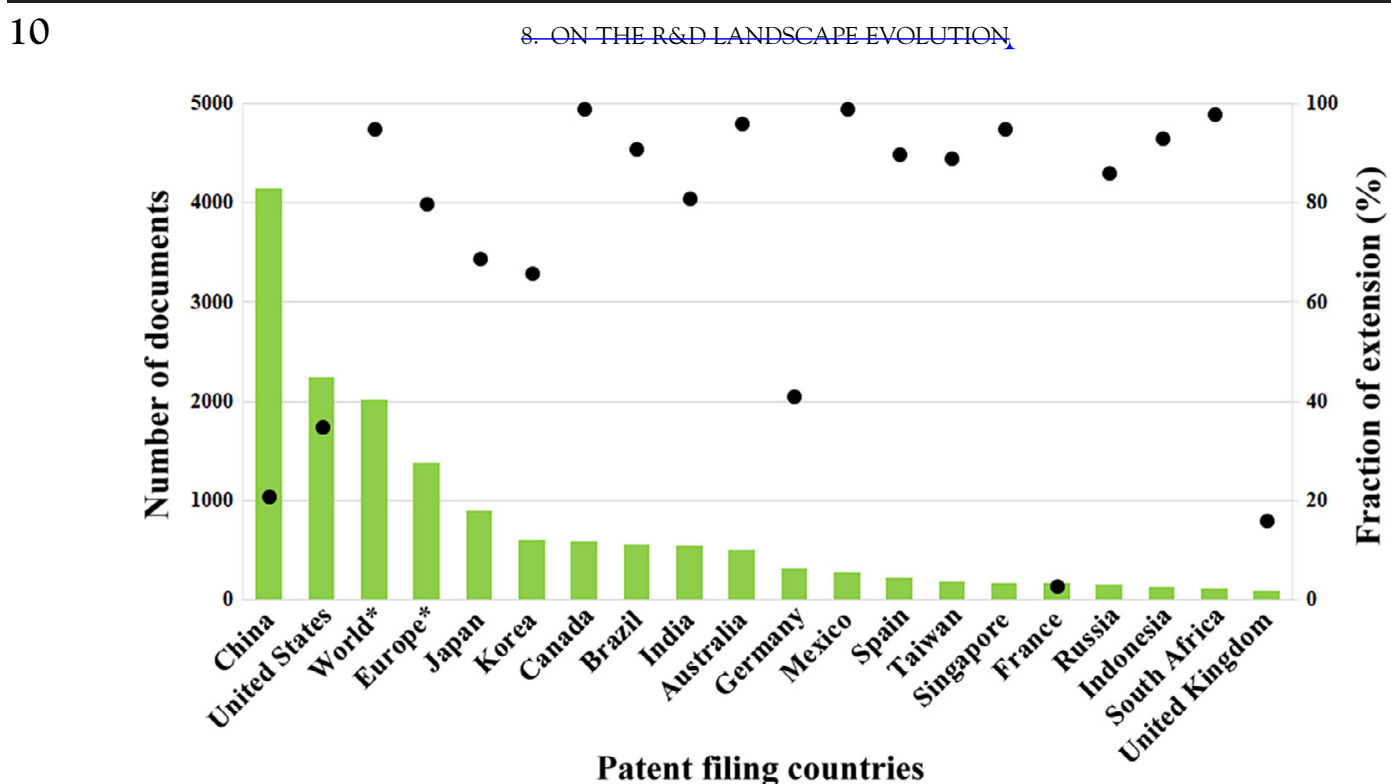

f0020 FIG. 8.3 The top 20 PL countries in the R\&D landscape study. The number of filed patents and the fraction of extended Q2 patents are represented by green bars and black dots, respectively.

t0015 TABLE 8.2 The Top 20 Patent Originated and Patent Extended Countries in the R\&D Landscape Study

\begin{tabular}{|c|c|c|c|c|c|c|c|c|c|}
\hline \multicolumn{5}{|c|}{ Top 20 Originating Countries } & \multicolumn{5}{|c|}{ Top 20 Extended Countries } \\
\hline Ranking & Country & Patent & $\begin{array}{l}\text { Share } \\
(\%)\end{array}$ & $\begin{array}{l}\text { Income } \\
\text { Level* }\end{array}$ & Ranking & Country & Patent & $\begin{array}{l}\text { Share } \\
(\%)\end{array}$ & $\begin{array}{l}\text { Income } \\
\text { Level* }\end{array}$ \\
\hline 1 & China & & 50.6 & $\begin{array}{l}\text { Upper- } \\
\text { middle }\end{array}$ & 1 & World* & 1920 & 20.2 & - \\
\hline 2 & United St & & 22.6 & High & 2 & Europe* & 1107 & 11.7 & - \\
\hline 3 & Japan & 277 & 4.3 & High & 3 & China & 863 & 9.1 & $\begin{array}{l}\text { Upper- } \\
\text { middle }\end{array}$ \\
\hline 4 & Europe & 272 & 4.2 & - & 4 & $\begin{array}{l}\text { United } \\
\text { States }\end{array}$ & 777 & 8.2 & High \\
\hline 5 & Korea & 202 & 3.1 & High & 5 & Japan & 620 & 6.5 & High \\
\hline 6 & Germany & 191 & 2.9 & High & 6 & Canada & 579 & 6.1 & High \\
\hline 7 & France & 165 & 2.5 & High & 7 & Brazil & 515 & 5.4 & $\begin{array}{l}\text { Upper- } \\
\text { middle }\end{array}$ \\
\hline 8 & India & 101 & 1.6 & $\begin{array}{l}\text { Lower- } \\
\text { middle }\end{array}$ & 8 & Australia & 491 & 5.2 & High \\
\hline 9 & World* & 100 & 1.5 & - & 9 & India & 443 & 4.7 & $\begin{array}{l}\text { Lower- } \\
\text { middle }\end{array}$ \\
\hline
\end{tabular}


B978-0-444-64127-4.00008-2, 00008

3 OVERALL TRENDS AND PATTERNS OF EVOLUTION

TABLE 8.2 The Top 20 Patent Originated and Patent Extended Countries in the R\&D Landscape Study—cont'd

\begin{tabular}{|c|c|c|c|c|c|c|c|c|c|}
\hline \multicolumn{5}{|c|}{ Top 20 Originating Countries } & \multicolumn{5}{|c|}{ Top 20 Extended Countries } \\
\hline Ranking & Country & Patent & $\begin{array}{l}\text { Share } \\
(\%)\end{array}$ & $\begin{array}{l}\text { Income } \\
\text { Level* }\end{array}$ & Ranking & Country & Patent & $\begin{array}{l}\text { Share } \\
(\%)\end{array}$ & $\begin{array}{l}\text { Income } \\
\text { Level* }\end{array}$ \\
\hline 10 & $\begin{array}{l}\text { United } \\
\text { Kingdom }\end{array}$ & 76 & 1.2 & High & 10 & Korea & 396 & 4.2 & High \\
\hline 11 & Brazil & 50 & 0.8 & $\begin{array}{l}\text { Upper- } \\
\text { middle }\end{array}$ & 11 & Mexico & 278 & 2.9 & $\begin{array}{l}\text { Upper- } \\
\text { middle }\end{array}$ \\
\hline 12 & Italy & 47 & 0.7 & High & 12 & Spain & 202 & 2.1 & High \\
\hline 13 & Russia & 23 & 0.4 & $\begin{array}{l}\text { Upper- } \\
\text { middle }\end{array}$ & 13 & Taiwan & 169 & 1.8 & High \\
\hline 14 & Spain & 23 & 0.4 & High & & Singapore & 168 & 1.8 & High \\
\hline 15 & Taiwan & 21 & 0.3 & High & 15 & Russia & 140 & 1.5 & $\begin{array}{l}\text { Upper- } \\
\text { middle }\end{array}$ \\
\hline 16 & Australia & 19 & 0.3 & & 16 & Germany & 134 & 1.4 & High \\
\hline 17 & Netherlands & 18 & 0.3 & & 17 & Indonesia & 128 & 1.3 & $\begin{array}{l}\text { Lower- } \\
\text { middle }\end{array}$ \\
\hline 18 & Finland & 17 & 0.3 & & 18 & $\begin{array}{l}\text { South } \\
\text { Africa }\end{array}$ & 115 & 1.2 & $\begin{array}{l}\text { Upper- } \\
\text { middle }\end{array}$ \\
\hline 19 & Denmark & 15 & 0.2 & High & 19 & $\begin{array}{l}\text { Hong } \\
\text { Kong }\end{array}$ & 70 & 0.7 & High \\
\hline 20 & Sweden & 14 & & High & 20 & Malaysia & 65 & 0.7 & $\begin{array}{l}\text { Upper- } \\
\text { middle }\end{array}$ \\
\hline
\end{tabular}

(India, Indonesia) and only $1.6 \%$ documents were produced in the rest of the world [8]. China (25.9\%) and the United States (14\%) are the leading countries of the PL collection in this R\&D andscape study. Moreover, China and the United States are the main drivers of global growth in patent filings with 50.6 and $22.6 \%$ of share as shown in Table 8.2. "World" (12.6\%) and "Europe" (8.6\%), ranked as third and fourth, respectively, representing the patent records corresponding to the number of PCT and European patent applications. Applying PCT and European patents after the first filing is a mainstream strategy for the entities and attorneys due to several strategy- and costaffecting factors such as maximizing delay in the granting procedures, allowing postponing decision on where else to file. In this R\&D landscape study, PCT $(20.2 \%)$ and European patent $(11.7 \%)$ extension applications were filed more than the national applications of other patentextended countries.

The Patent Cooperation Treaty (PCT) is an p0135 international treaty under which a single international patent application can be filed for patent protection in up to 144 countries where patent protection is desired [7]. The filing of an international application will automatically constitute the designation of all contracting countries to the PCT on that filing date and the priority date will result in an extension of the period for entering the national stage to 
30 months from the priority date [9]. Entering the national stage through European patent extends the priority date 31 months from the first filing date as the regulations and processes differ across national patent offices. The European patent is a patent which can be obtained for 38 contracting states of the European Patent Convention by filing a single application with the European Patent Office (EPO). European patents granted by the EPO have the same legal rights and are subject to the same conditions as national patents granted by the respective national patent office. A granted European patent is a bundle of national patents which becomes effective upon validation by the national patent offices of the countries selected by the applicant, after the official fees are paid $[7,9]$.

p0140 In Fig. 8.3, the black dots represent the percentage of the extended patents on the sum of originated and extended patents in a specified country (called "fraction"). Because it is a preferable route for the entities to apply for a PCT or European patent after the national patent application, World and Europe have a high fraction ratio. The geographic coverage of a patent can be expanded in the countries in which protection of the invention is desired within a certain period of time. The fraction ratio corresponds the extended patents in a country to the sum of originated and extended patents in that specified country. A low fraction in a given country means that fewer countries are extending their originating patents to this country. The countries with the lower fraction ratio are France, the United Kingdom, China, the United States, Germany, Korea, Japan, and India; whereas the countries with the higher fraction ratio are Russia, Taiwan, Spain, Brazil, Indonesia, Singapore, Australia, South Africa, Canada, and Mexico. Higher fraction would be an indication of opportunities of deploying the patent-protected technology which can be linked to the fast development nature of the country or to its presence of large amounts of biomass. In Brazil, known as one of leading countries in biomass; only
50 patent applications have been filed, whereas 515 patent records were extended [10]. In other words, global entities extended the number of patents originated in Brazil more than tenfold. The trend in Brazil and Brazil-like countries highlights that these countries have potentially high amounts of assessable biomass resources, including where the new biomass-related technologies might be implemented.

Fig. 8.4 illustrates the intersections of top p0145 20 patent-originating countries and top 20 patent-extending countries for the patent records covered in the R\&D landscape study. It is clearly seen that the United States is the major player as an overwhelming number of U.S.-originated patents not only extend through PCT or European applications but were filed throughout the world. China, Canada, and Brazil are the top three countries in where U.S.-originated patents extend the most. Contrarily, even though China is the first ranked country with $50.6 \%$ of the share and an important key player of global growth in patent filings (see Table 8.2), entities filing applications for Chinese patents follow a different behavior and rarely expand the geographical coverage of Chinese patent applications in other countries. This is undoubtedly due to the fact that China is a paramount production hub so most of the entities from other countries file by extending in China to protect their inventions. However, Chinese entities focus on protecting their technology which reflects that they stay local and have little intention of deploying their technology outside China.

\section{TECHNICAL ANALYSIS OF CATALYTIC CONVERSION OF RENEWABLE BIOMASS}

This section provides detailed information p0150 and statistics that were obtained from the collections of PL and NPL in catalytic upgrading of biomass over the last two decades. The analysis not only allows making comparisons between 


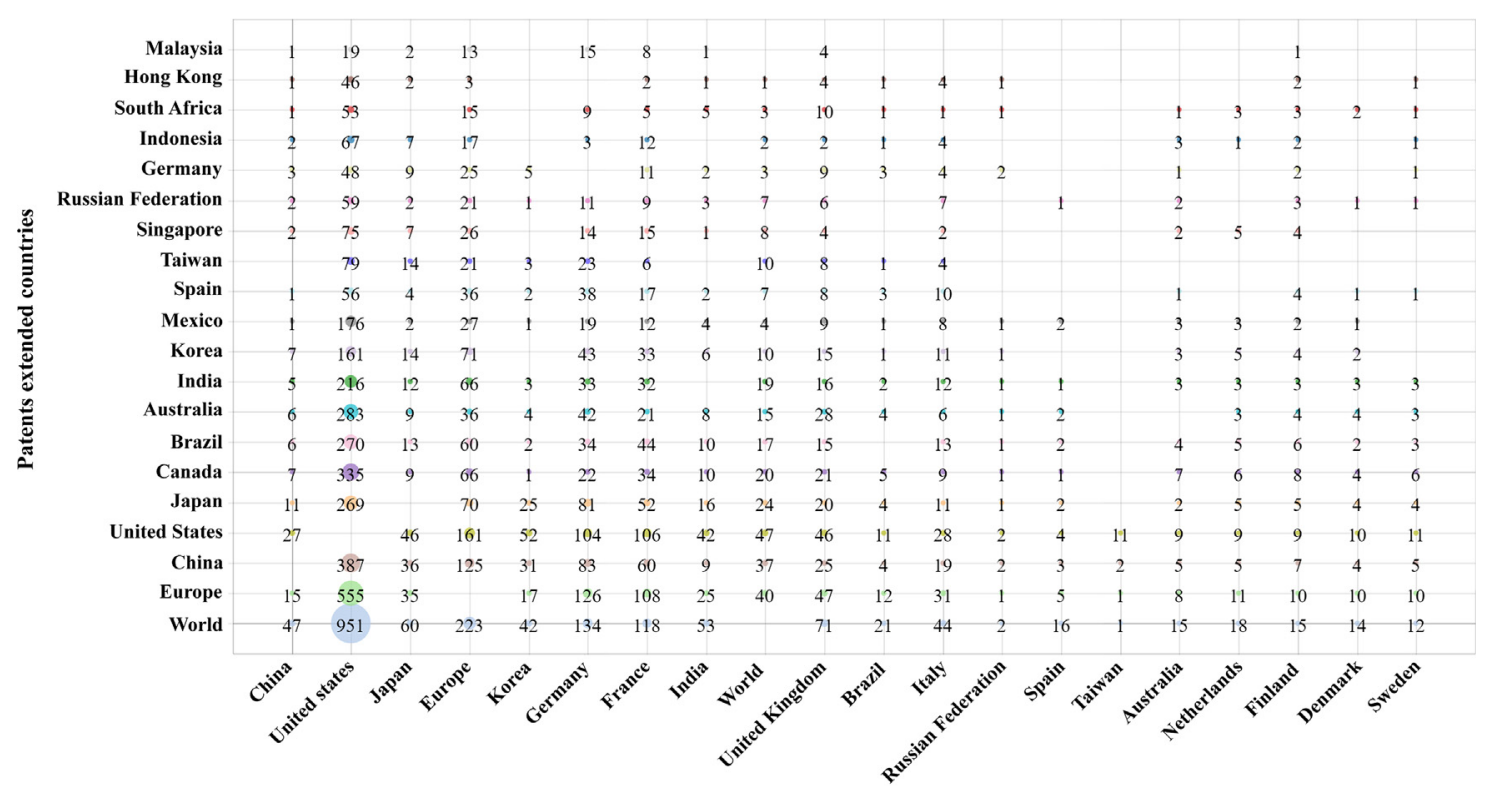

\section{Patents originating countries}

FIG. 8.4 The top 20 patent-originating and patent-extending countries for the patent documents covered in the R\&D landscape study.

PL and NPL collections within the technology scope of the R\&D landscape study, but also focuses on the patterns of evolution in various technical fields regarding heterogeneous catalysis, feedstock types, biomass conversion processes, and corresponding solid catalysts and biomass-derived chemicals. The technical field analyses were performed by counting the number of hits in the detailed, enriched, and verified custom fields on Intellixir.

p0155 Fig. 8.5 illustrates the temporal distribution of patent families and nonpatent literature publications associated with solid catalysis which are categorized in 4 main groups: metal, acid, base, and electro-catalysis with a distribution of $45.8 \%$, $34.5 \%, 12.3 \%$, and $7.4 \%$ respectively. This categorization is arbitrary but reflects the typical types of heterogeneous catalysis. Acid and base catalysis are related to clear distinguishable mechanism of catalysis, protonation (or electron withdrawal, generating intermediate cations), and deprotonation (or electron donation, generating intermediate anions) linked to the nucleophilic or electrophilic nature of the substrate. Metal catalysis is still a broad field of catalysis characterized by many different mechanisms, but in general terms metal catalysis is about redox reactions like hydrogenation-dehydrogenation and reduction-oxidation. Electrocatalysis has been regarded as a particular class of catalysis as it is an emerging field, although it can be considered part of metal catalysis that implies electrochemical reactions. Where in other types of catalysis the reaction of or between chemicals is accelerated, electrocatalysts assist in the transfer of electrons from or to power sources between the electrodes and reactants or products, and hence accelerate the transformation into a selective product by an overall half-reaction. They are thermodynamically governed by the total energy available to do work (e.g., producing electricity instead of reaction heat like in a fuel cell or 
14

8. ON THE RE LANDSEAPE EVOLUTIOA

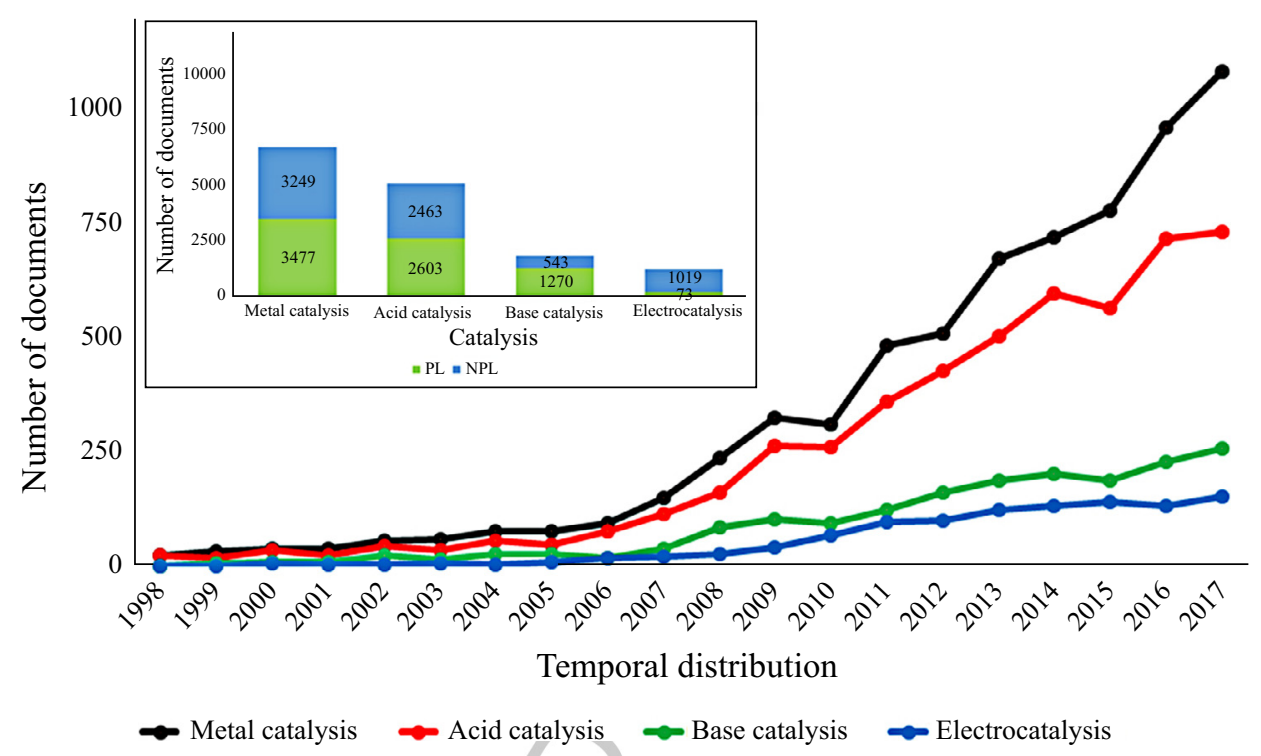

f0030 FIG. 8.5 Temporal distribution of heterogeneous catalysis-related documents within the PL and NPL collections of the R\&D landscape study. Metal, acid, base and electrocatalysis are represented by black, red, green, and blue lines, respectively.

consuming electricity instead of high temperature heat for thermolysis/electrolysis of water).

p0160 It is notable that $50.5 \%$ of documents, which responded to the related custom field value strings used for the temporal distribution of catalysis, come from PL publications while $49.5 \%$ of them are among the NPL documents of the entire collection. The total number of documents categorized in the four fields of catalysis is significantly higher in case of PL (7423 [115\%] categorized versus 6485 original documents), while lower in the case of NPL (7274 [92\%] categorized versus 7866 original documents). No detailed explanation has been looked into for this but it may point to a lessspecific nature of patents (a broader scope of claims in general) compared to scientific publications or eventually the use of multifunctional catalysts in PL, reflecting the industrial innovation purpose of patents where often a final marketable product is envisioned (requiring multifunctional conversions). But in a scientific publication, a precise catalytic composition or reaction is elucidated. From 2007 onwards, rapid growth is observed in metal and acid catalysis-related publications covered in the R\&D landscape study. Base catalysis and electrocatalysis seem not yet to have found a large place in biomass upgrading. However, it might be expected that the potential of electrocatalysis is high, as electrocatalysis allows the catalyzing of very specific reactions, in particular, for temperature-sensitive reactants or products, as they often occur at reasonably low temperatures. The use of electrons in reducing reactions is an appropriate way to convert highly oxygenated compounds (where carbon has a fairly high formal oxidation state, around 0 for sugars and around -1 for lignin) into hydrocarbon type compounds (where carbon has a low formal oxidation state, between -2 and -3 ). Reaction mechanisms, which require base catalysis (typically nucleophilic), are less appropriate as a highly oxygenated biomass is itself already rather nucleophilic and hence less prone to nucleophilic activation. 


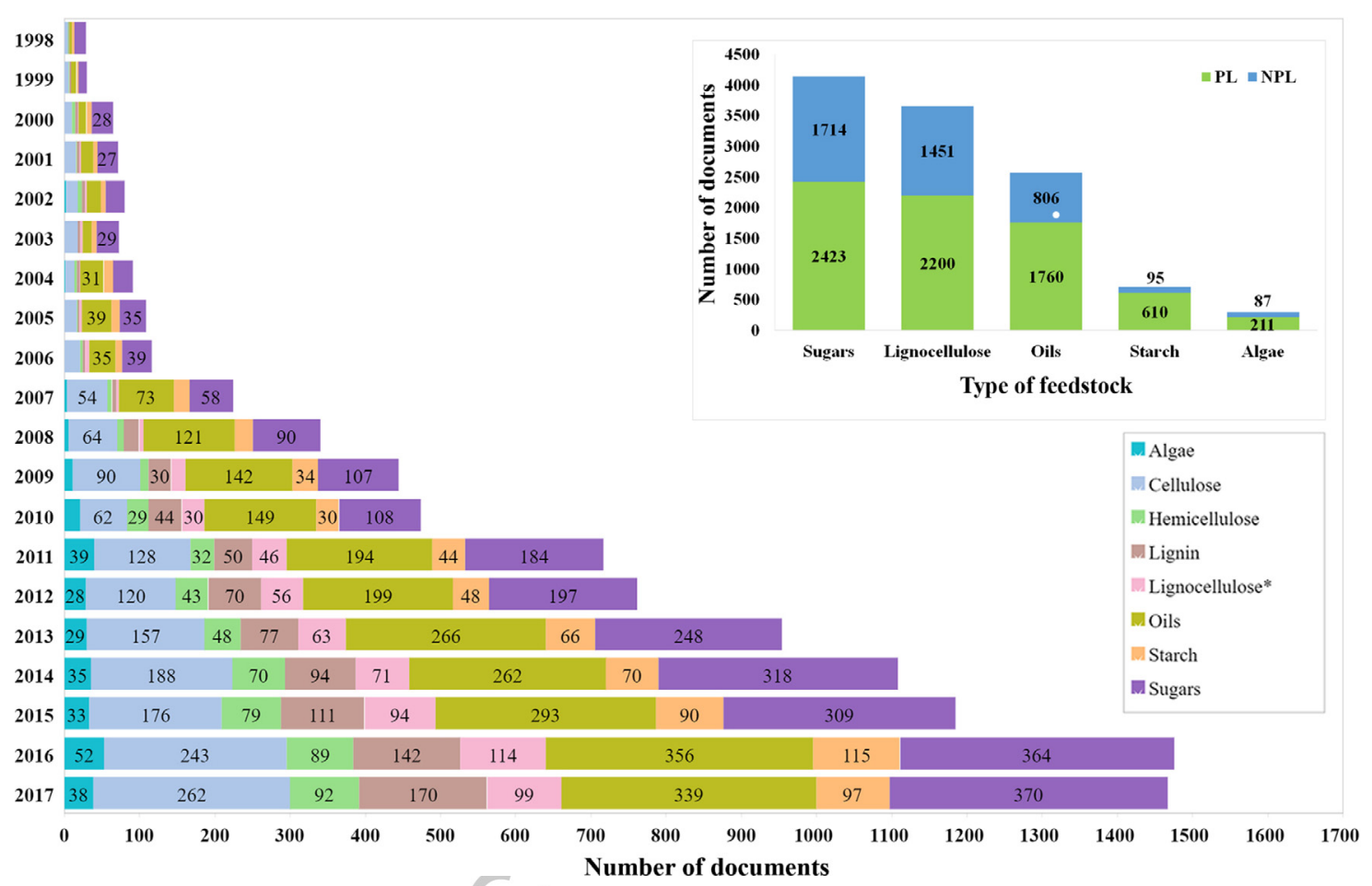

f0035 FIG. 8.6 Temporal distribution of feedstock-related documents within the PL and NPL collections of the R\&D landscape study.

p0165 Fig. 8.6 illustrates the temporal distribution of patent families and nonpatent literature publications associated with different types of biomass feedstock used in the catalytic transformation. In principle, they all originate from biomass, but such categorization reflects the need for isolated and purified components of it in order to use heterogeneous catalysts for the transformation. As shown in the inner Fig. 8.6, the types of biomass feedstock are clustered in five main groups: sugars (glucose, fructose, sucrose, xylose, lactose, and arabinose), lignocellulose (lignocellulose, cellulose, hemicellulose, and lignin), oils, starch, and algae with a distribution of $36 \%, 32 \%, 23 \%$, $6 \%$, and $3 \%$, respectively. Sixty-three percent of documents, which responded the related custom field value strings used for the temporal distribution of biomass feedstock type, come from PL publications, while $37 \%$ of them are among the NPL documents of the entire collection. This distribution of responses is in line with the documents on types of catalysis, again reflecting the dominancy of PL. As mentioned earlier, the increase over the last decade in PL and NPL publications on biomass conversion is striking, as seen on the main graph in Fig. 8.6. Here, the occurrence of different subclasses of biomass reported in the document's title, abstract, or keywords have been counted against time. 2007 was the pivotal year, with a nearly exponential growth in publications. A twofold-or-more increase of publication numbers between 2011 and 2017 was observed for all types of feedstock with exception of algae. The stagnation in the number of algae-related documents can be explained by their complex nature (typically the 
order of components occurrence is: proteins $>$ carbohydrates $>$ lipids) but certainly by their still-lower availability compared to lignocellulosic materials like wood and agricultural crops or wastes (rich in carbohydrates and lignin but with very little proteins). However, it should be considered that fermentation-like processes (enzymatic, microbial, and bacterial) and thermal conversion processes (pyrolysis and hydrothermal conversion, typically employed as first process step to upgrade algaes) were out of the technology scope of this R\&D study. Moreover, lignin, seen as a byproduct/waste from lignocelluloses fractionation to obtain carbohydrates, receives enhanced attention for catalytic conversion. A similar trend is seen for hemicelluloses, another fraction of lignocelluloses obtained as waste of cellulose extraction.

p0170 Fig. 8.7 shows the top 25 biomass conversion processes (reflecting the type of chemical transformation) and the corresponding solid acid, base, metal, or electrocatalysts within the PL and NPL collections of the R\&D landscape study. The occurrence numbers, at the intersections of conversion processes and type of catalysis, corresponds to the number of documents that fulfill the retrieval criteria for the associated values of the custom fields generated on Intellixir.

The subset of metal catalysts has been p0175 expanded according to the most reported types of metals. The rationale is that often each metal has a particular catalytic effect and hence catalyzes a given reaction with the appropriate selectivity for a given product. This means that the mechanisms of metal-catalyzed reactions are in general very different from one metal to another. In the case of acid and base catalysts, the reaction mechanism is, in general, less differentiatedacid catalysts have the ability to deliver protons, whereas basic catalysts abstract protons. Electrocatalysis is essentially linked to oxidation reactions. Most publications deal with fuel cell applications, where electrons are transferred
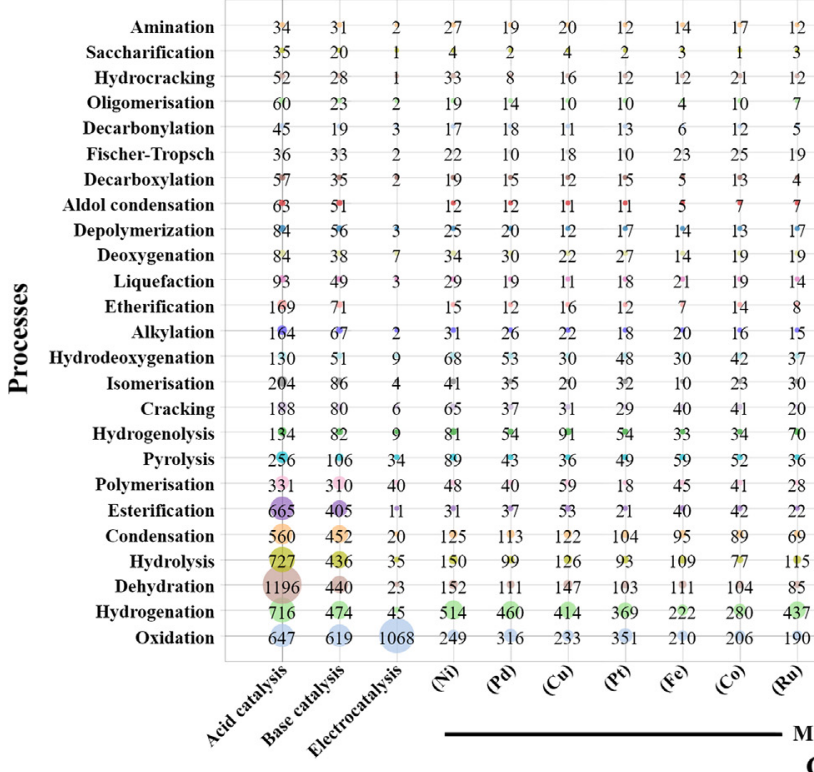

\begin{tabular}{|c|c|c|}
\hline 13 & 10 & 8 \\
\hline 2 & 1 & 1 \\
\hline 10 & 19 & 2 \\
\hline 7 & 3 & 1 \\
\hline 13 & 7 & 1 \\
\hline 12 & 16 & 5 \\
\hline 16 & 12 & 2 \\
\hline 3 & 2 & 2 \\
\hline 14 & 22 & 2 \\
\hline 15 & 36 & 6 \\
\hline 15 & 17 & 3 \\
\hline 18 & 8 & 3 \\
\hline 26 & 12 & 7 \\
\hline 14 & 50 & 9 \\
\hline 16 & 24 & 5 \\
\hline 29 & 38 & 4 \\
\hline 28 & 20 & 7 \\
\hline 27 & 52 & 7 \\
\hline 96 & 33 & 12 \\
\hline 83 & 25 & 24 \\
\hline 126 & 63 & 36 \\
\hline 89 & 57 & 31 \\
\hline 129 & 60 & 34 \\
\hline 209 & 214 & 118 \\
\hline
\end{tabular}

\begin{tabular}{|ccc}
9 & 6 & 10 \\
2 & 1 & 2 \\
6 & 16 & 6 \\
5 & 3 & 3 \\
3 & 6 & 7 \\
10 & 9 & 8 \\
3 & 11 & 7 \\
3 & 3 & 3 \\
6 & 15 & 7 \\
11 & 22 & 8 \\
13 & 11 & 4 \\
5 & 10 & 9 \\
11 & 10 & 12 \\
16 & 29 & 4 \\
11 & 18 & 11 \\
17 & 30 & 12 \\
30 & 34 & 11 \\
27 & 38 & 14 \\
13 & 29 & 29 \\
15 & 34 & 30 \\
\hline 60 & 48 & 54 \\
45 & 52 & 34 \\
60 & 73 & 55 \\
\hline 215 & 167 & 106 \\
\hline 15 & 106 & 160
\end{tabular}

से से के

Catalysis

f0040 FIG. 8.7 The top 25 biomass conversion processes and corresponding solid catalysts (the group of metal catalysts has been expanded according to metal type) within the PL and NPL collections of the R\&D landscape study. 
from fuels to molecular oxygen. Acid catalysts are essentially linked to types of reactions like dehydration, hydrolysis, condensation, cracking, isomerization, esterification, and polymerization. The significant intersection between hydrogenation and oxidation with acid catalysis is explained by bifunctional catalysts requiring both an acid and a metal function, or by a combination of different kinds of consecutive reactions and hence catalytic functions. A typical example is the synthesis of FDCA from sugars, requiring acid-catalyzed isomerization of glucose into fructose, acid-catalyzed dehydration into HMF, and several further oxidation steps using metal-type catalysts. Basic catalysis is in particular important for condensation (carboncarbon bond formation) and esterification (e.g., biodiesel synthesis from triglycerides to methylesters). Moreover, the basic nature of the supports for hydrogenation and oxidation metalcatalyzed reactions explains the significant amount of intersection hits matching for these processes with basic catalysis. Base-catalyzed dehydration is presumably related to several condensation reactions including a dehydration step making enones or enals (conjugated ketons/aldehydes).

p0180 In 2004, the US Department of Energy (DOE) identified the top 12 most-relevant compounds derived from biorefinery carbohydrates [11]. Twelve building block chemicals (molecules with multiple functional groups, which can be transformed into other marketable derivatives and which can be produced from carbohydrates via biological or chemical conversions, were described in detail. The 12 sugar-based building blocks are 1,4-diacids (succinic, fumaric, and malic), 2,5-furan dicarboxylic acid, 3-hydroxy propionic acid, aspartic acid, glucaric acid, glutamic acid, itaconic acid, levulinic acid, 3-hydroxybutyrolactone, glycerol, sorbitol, and xylitol/arabinitol. The selection was based on the potential of such molecules for further development in commercially valuable products. The intent of the report was to catalyze research efforts to develop industrial applications and identify the common challenges and barriers of associated production technologies. In 2010, Bozell et al. reported on the considerable progress made in the use of carbohydrates as starting materials for chemical production [12].

Fig. 8.8 displays the temporal distribution of p0185 the top 25 biomass-derived chemicals within the PL and NPL collections of the R\&D landscape study over the last two decades. The selection of the top 25 is merely based on the occurrence of documents reporting them. The feedstock is now not limited to carbohydrates but includes all lignocellulosic biomass. The custom field-value string for each biomass-based chemical was based on a search within title, abstract, and keywords for NPL documents; and within title, abstract, and claims for PL documents among the entire collection and on retrieval of the matching documents. The only exception was performed for ethanol, due to unacceptable high noise in the results. Although a decrease in the actual number of ethanolrelated documents was expected, the value string was limited to the title for PL and NPL documents in order to have more sensible results. The general trend for biomass-derived chemicals is a steady growth over time. However, the activity on given molecules and their growth rates vary from one to another. In order to better monitor their patterns of evolution, compound annual growth rates (CAGR) of the top 25 biomass-derived chemicals were evaluated between 1998 and 2007, 2008 and 2017, and 1998 and 2017, as reported in Table 8.3, which also summarizes the percentage of PL documents with the total number of PL and NPL documents for each biochemical. The color-ranking was applied to each column to illustrate the numeric comparison. Each cell of a column has a shade of color, shifting from dark green for the highest numeric value, to lighter colors, and ultimately dark red for the lowest numeric value in the column. The highest growth rates through the whole 1998-to-2017 


\section{8. ON THE REDANDSGAPE EVOLUTION}

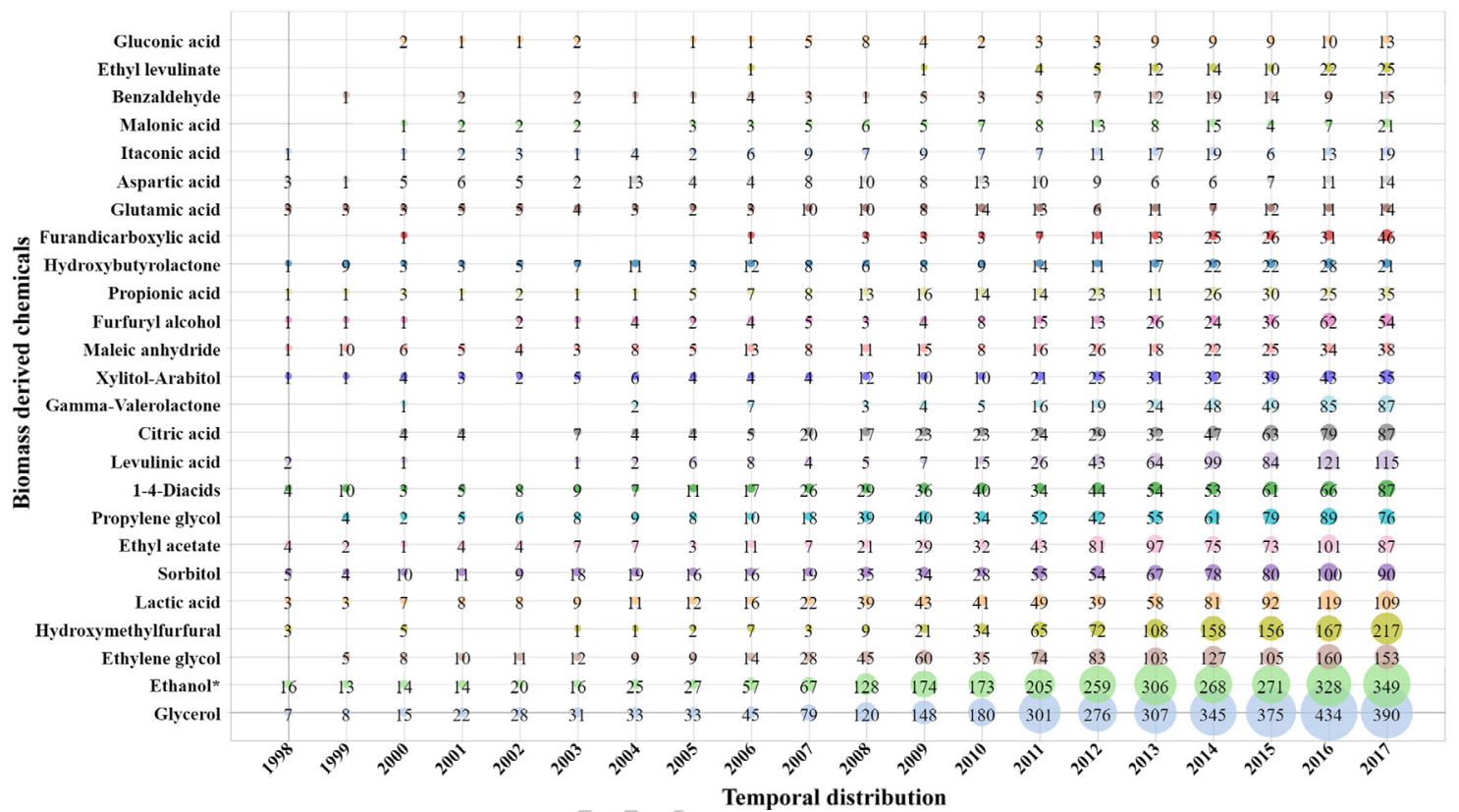

f0045 FIG. 8.8 Temporal distribution of the top 25 biomass-derived chemicals within the PL and NPL collections of the R\&D landscape study.

period, among these 25 biochemicals are observed for glycerol, ethanol, ethylene glycol, and 5-hydroxymethylfurfural. Their greenshaded cells indicate where the CAGR is well above the average. The presentation of the data of the decades 1998-2007 and 2008-2017 in two separate columns allows to identify some tendencies of evolution of the compound growth rate. The CAGR of maleic anhydride, hydroxybutyrolactone, and some organic acids (propionic, malonic, itaconic, gluconic, glutamic, and aspartic acid) are lower in the last of the two decades, with lower publication activity. Their white-colored cells indicated that there was an attention for them over the previous decade; whereas the color change of the cells to red, where the CAGR is below the average, indicates that attention on those chemicals decreased over the last decade. In particular the latter organic acids, which were considered in the top 12 in 2004, are not presently receiving the expected attention. Contrarily, 5-hydroxymethylfurfural (HMF), levulinic acid, gamma-valerolactone, furfuryl alcohol, and 2,5-furandicarboxylic acid (FDCA), follow an opposite trend. These promising compounds have a negligible number of Q14 records belonging to the previous decade (low CAGR between 1998 and 2007, represented by the red cells) in comparison to the last decade (high CAGR between 2008 and 2017, represented by green cells), in which the number of patent and nonpatent literature publications has boosted dramatically. Explicitly, HMF and levulinic acid are the most attentiondrawing molecules with 1029 and 603 PL and NPL records, respectively.

The number of hits of conversion processes p0190 and type of catalyst corresponding to each of the top 25 biomass-derived chemicals within the PL and NPL collections of the R\&D landscape study are shown in Figs. 8.9 and 8.10. It should be remembered that computer-based 
B978-0-444-64127-4.00008-2, 00008

TABLE 8.3 Evaluation of the Top 25 Biomass-Derived Chemicals Within the PL and NPL Collections of the R\&D Landscape Study

\begin{tabular}{|c|c|c|c|c|c|}
\hline $\begin{array}{l}\text { Biomass derived } \\
\text { chemical }\end{array}$ & $\begin{array}{c}\text { Cagr (\%) } \\
(1998-2007)\end{array}$ & $\begin{array}{c}\text { Cagr (\%) } \\
(2008-2017)\end{array}$ & $\begin{array}{c}\text { Cagr (\%) } \\
(1998-2017)\end{array}$ & PL $(\%)$ & $\begin{array}{c}\text { \# of PL and NPL } \\
\text { documents }\end{array}$ \\
\hline Glycerol & 61.1 & 81.7 & 36.8 & 44 & 3177 \\
\hline Ethanol* & 58.9 & 78.9 & 35.8 & 29 & 2730 \\
\hline Ethylene glycol & 46.0 & 65.0 & 30.3 & 79 & 1051 \\
\hline Propylene glycol & 42.3 & 50.1 & 25.6 & 27 & 637 \\
\hline Lactic acid & 41.7 & 58.3 & 27.8 & 58 & 769 \\
\hline 1-4-Diacids & 39.4 & 53.7 & 26.2 & 64 & 604 \\
\hline Sorbitol & 38.5 & 54.7 & 26.3 & 85 & 748 \\
\hline Citric acid & 36.0 & 56.0 & 26.5 & 84 & 472 \\
\hline Ethyl acetate & 27.4 & 57.1 & 26.2 & 82 & 689 \\
\hline Xylitol-arabitol & 22.7 & 50.0 & 23.4 & 33 & 312 \\
\hline Maleic anhydride & 25.3 & 42.3 & 20.9 & 90 & 276 \\
\hline Propionic acid & 26.7 & 40.0 & 20.4 & 31 & 237 \\
\hline Malonic acid & 19.7 & 33.4 & 17.4 & 71 & 112 \\
\hline Hydroxybutyrolactone & 20.8 & 32.0 & 17.1 & 90 & 220 \\
\hline Itaconic acid & 22.7 & 28.7 & 16.4 & 37 & 144 \\
\hline Gluconic acid & 21.8 & 21.8 & 14.5 & 89 & 83 \\
\hline Glutamic acid & 22.7 & 15.7 & 13.5 & 68 & 147 \\
\hline Aspartic acid & 20.8 & 18.5 & 13.5 & 48 & 145 \\
\hline Hydroxymethylfurfural & 12.3 & 75.7 & 32.6 & 56 & 1029 \\
\hline Levulinic acid & 10.1 & 64.1 & 28.2 & 57 & 603 \\
\hline Gamma-valerolactone & 4.4 & 59.7 & 26.5 & 85 & 350 \\
\hline Furfuryl alcohol & 12.3 & 51.0 & 23.2 & 95 & 266 \\
\hline Furandicarboxylic acid & 4.4 & 49.1 & 22.3 & 65 & 170 \\
\hline Ethyl levulinate & 0.0 & 40.3 & 18.5 & 21 & 94 \\
\hline Benzaldehyde & 7.6 & 31.0 & 15.3 & 73 & 104 \\
\hline
\end{tabular}

text-mining does not differentiate between biochemicals, which are reactant, intermediate, or products. Hence the intersections merely refer to the link between each chemical and conversion process or type of catalyst.

p0195 Some specific examples illustrate the richness of information which can be drawn from open NPL and PL. Fig. 8.11 displays a schematic illustration of the relationship between the most promising biomass-derived chemicals of the last decade: 5-hydroxymethylfurfural (HMF), levulinic acid, gamma-valerolactone, furfuryl alcohol, 2,5-furandicarboxylic acid, and ethyl levulinate.
HMF, an important bio-based platform mole- p0200 cule for the production of liquid fuels and fine chemicals, is a dehydration product of monosaccharides. Various effective and reusable heterogeneous catalysts are utilized, instead of homogeneous acids, for the selective dehydration of glucose and/or fructose to HMF, such as Amberlyst-15 [13], mesoporous tantalum phosphate or tantalum oxide [14,15], binderless zirconium phosphate coating on aluminum foam [16], Zr containing mesoporous MCM41 silica [17], H-, Fe- and Cu-ZSM-5 [18], layered zirconosilicate [19], zirconium phosphate [20], phosphotungstic acid encapsulated in 
B978-0-444-64127-4.00008-2, 00008

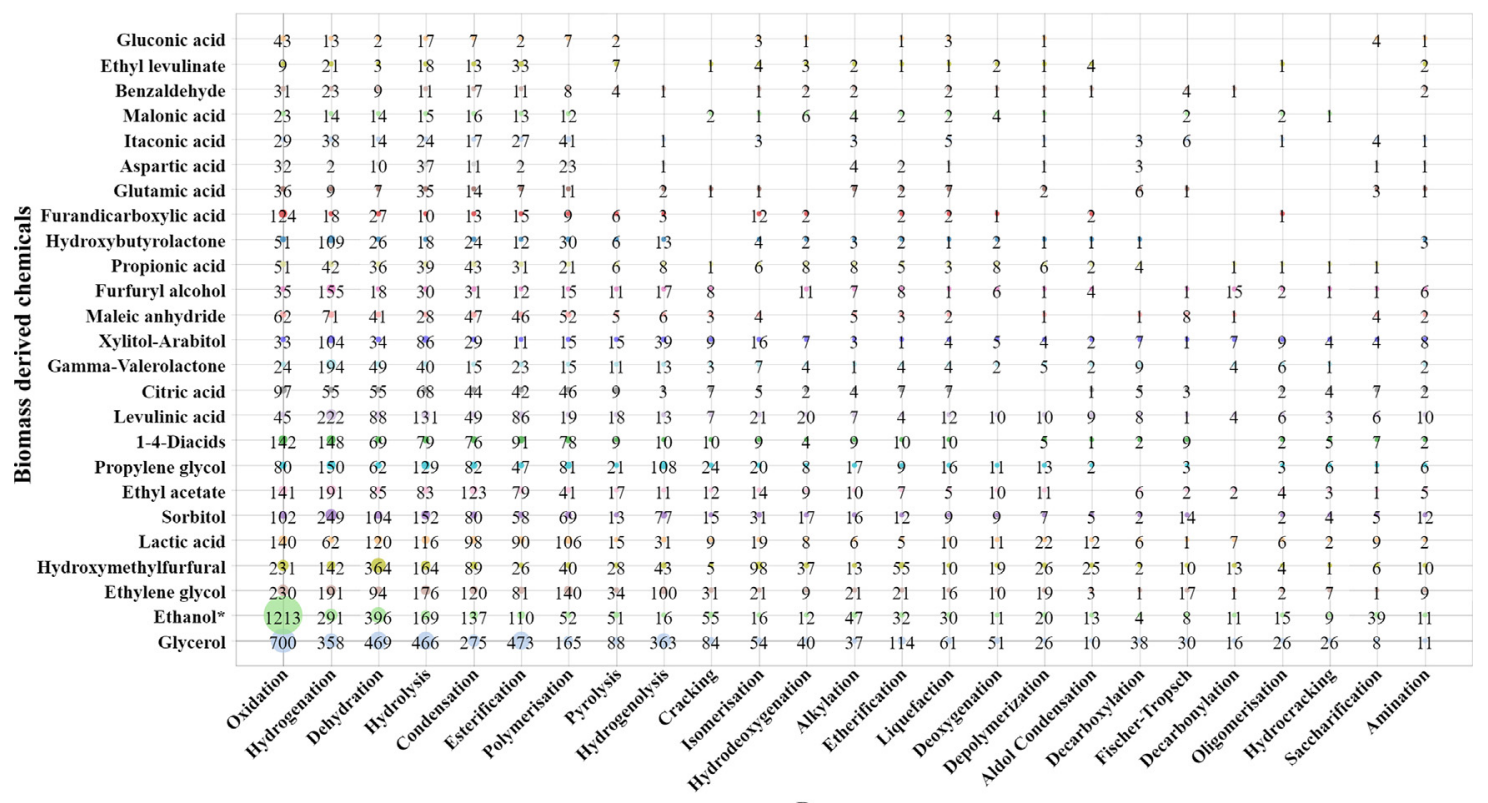

Processes

f0050 FIG. 8.9 The top 25 biomass-derived chemicals and corresponding conversion processes within the PL and NPL collections of the R\&D landscape study.

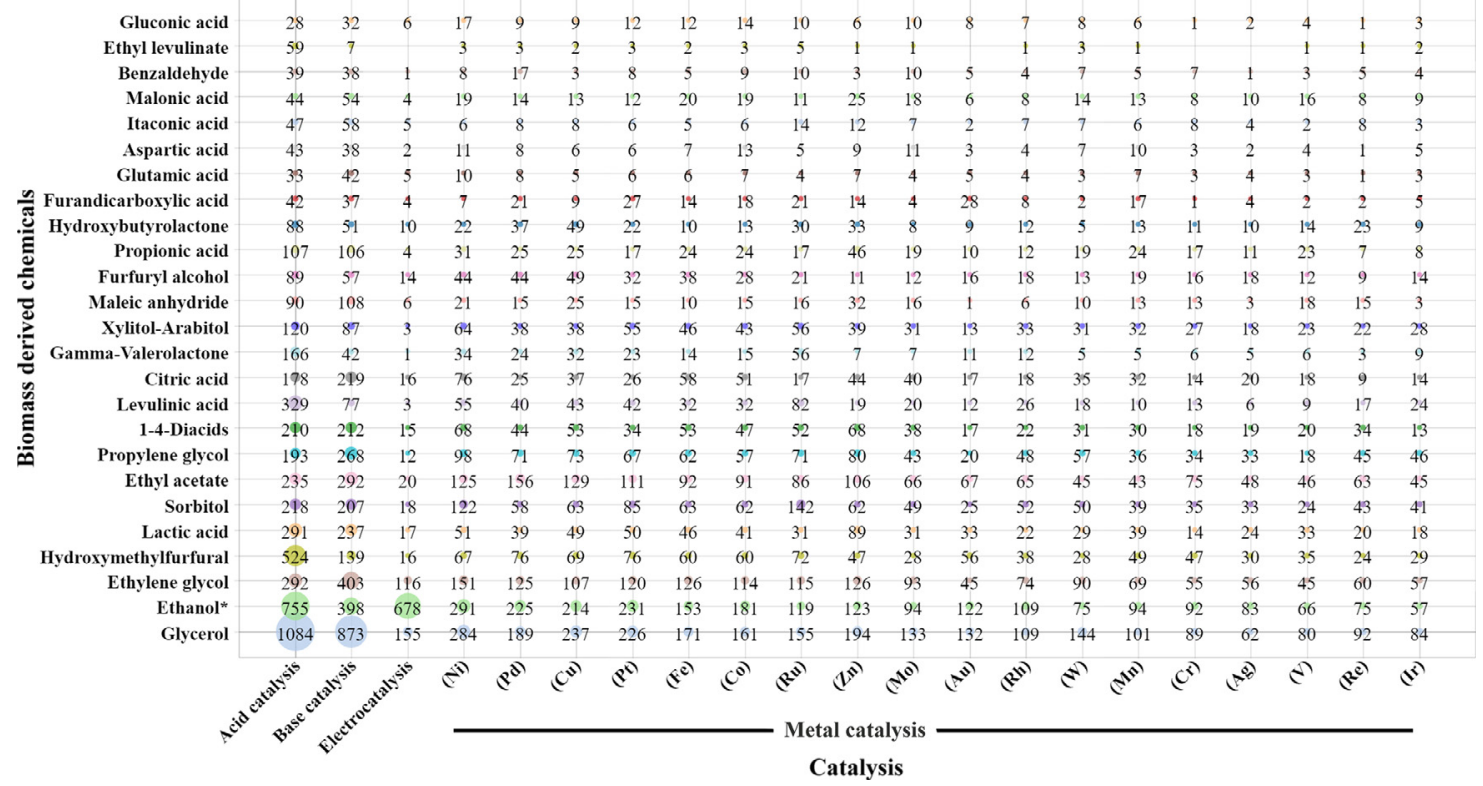

f0055 FIG. 8.10 The top 25 biomass-derived chemicals and corresponding solid catalysts within the PL and NPL collections of the R\&D landscape study. 


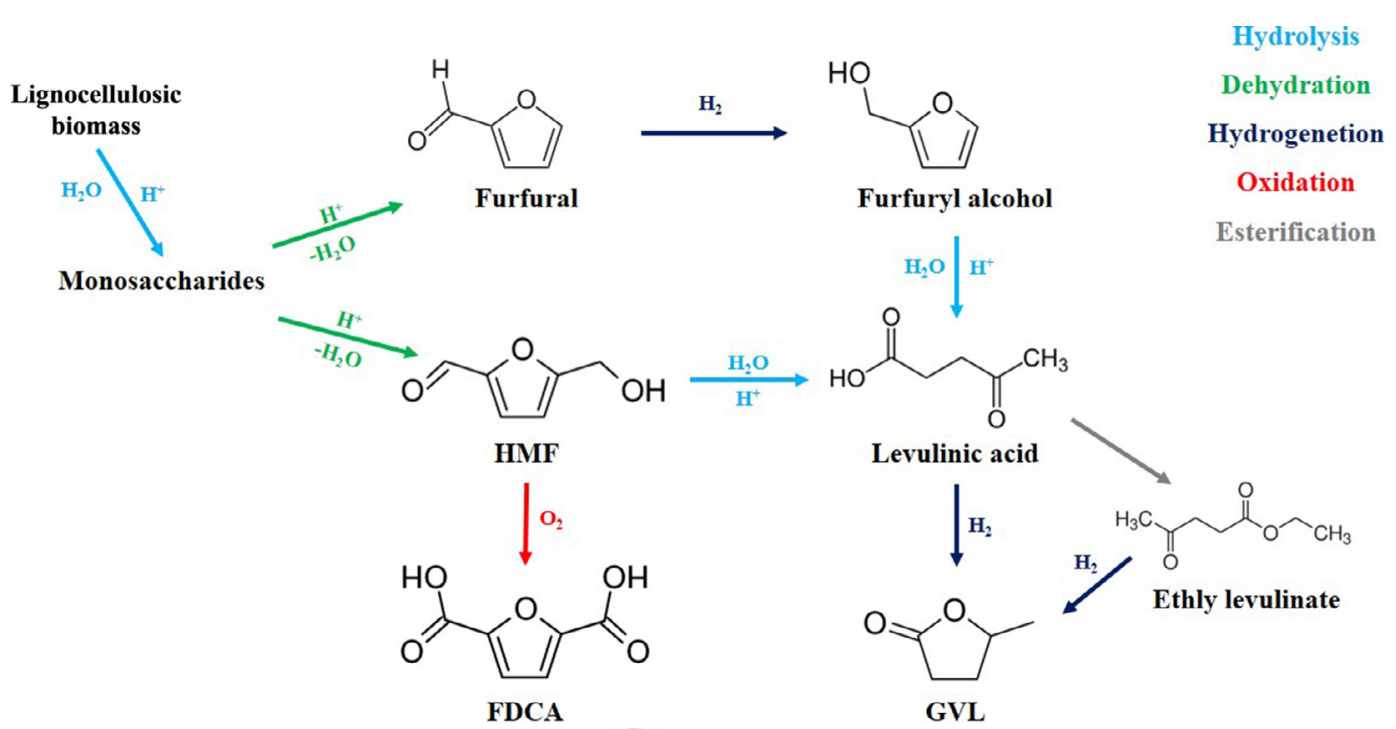

f0060 FIG. 8.11 The schematic illustration of the relations between the most attractive value-added biomass-derived chemicals over the last decade.

metal-organic framework [21], mesoporous niobium phosphate [22], sulfated $\mathrm{ZrO}_{2}$ hollow [23], Cr-based heteropoly acid ionic crystal [24], and phosphorylated mesoporous carbons [25].

p0205 The cascade oxidation process of HMF, involving several intermediates in parallel or successive reactions, allows synthesizing 2,5furandicarboxylic acid. FDCA is one of the most attractive reactions for establishing biomassbased sustainable chemical processes. It is a promising renewable alternative to petroleumderived terephthalic acid as a polymer precursor to produce recyclable biobased polymers, similar to PET. Pd-modified Au on carbon [26], carbon nanotube supported $\mathrm{Au}-\mathrm{Pd}$ alloy [27], gold nanoparticles supported on nanoparticulate ceria and on titania [28], Pt-loaded reduced graphene oxide [29], $\mathrm{Pt} /$ gamma- $\mathrm{Al}_{2} \mathrm{O}_{3}$ [30], $\mathrm{MnCo}_{2} \mathrm{O}_{4}$ spinel supported $\mathrm{Ru}$ catalyst [31], nano- $\mathrm{Fe}_{3} \mathrm{O}_{4}-\mathrm{CoO}_{x}$ [32], $\mathrm{MnO}_{x}-\mathrm{CeO}_{2}$ mixed oxides [33], and $\mathrm{MnO}_{2}$ [34] have been proposed as selective oxidation catalysts.

p0210 Levulinic acid is considered as a versatile building block because it can be used for the synthesis of several organic chemicals. Levulinic acid is formed by dehydration in acidic media of sugars to HMF which, upon subsequent hydration, produces levulinic acid, along with equimolar amounts of formic acid. Bimetallic oxide catalysts, such as $\mathrm{WO}_{3}-\mathrm{Ta}_{2} \mathrm{O}_{5}$, are promising to simplify the process of converting saccharides into HMF and levulinic acid in onepot reactions [35]. The alternative process involves the dehydration of saccharides to furfural, subsequent hydrogenation to furfuryl alcohol which is finally hydrolyzed to levulinic acid. Cu-doped niobium phosphate catalysts could catalyze furfural conversion to levulinic acid through a one pot single-step process. [36] The one-pot reactions are attractive due to exempting the separation and purification processes of the intermediates.

Ethyl levulinate, a biofuel additive, can be pro- p0215 duced through the esterification reaction of levulinic acid with ethanol catalyzed by amberlyst- 15 and sulfated $\mathrm{SnO}_{2}$ [37], both $\mathrm{ZrO}_{2}$-supported phosphotungstic acid catalysts [38,39]. Furthermore, zirconium-based MOFs [40] using 
isopropanol as a hydrogen donor could be applied for catalytic transfer hydrogenation of ethyl levulinate to form gamma-Valerolactone (GVL), which is one of the paramount building blocks for the production of fuels and chemicals based on renewable feedstocks. As an alternative route, GVL can be obtained directly by the hydrogenation of levulinic acid, can be catalyzed by a ruthenium-supported catalyst in combination with a heterogeneous acid cocatalyst, such as the ion exchange resins Amberlyst A70 or A15, niobium phosphate, or oxides [41,42]. Additionally, $\mathrm{Ru}, \mathrm{Pt}$, and $\mathrm{Pd}$ noble metals supported on carbon [43], $\mathrm{Ru}-\mathrm{P} / \mathrm{SiO}_{2}$ [44], $\mathrm{Ni} / \mathrm{SiO}_{2}$ [45], RuSn bimetallic catalysts [46], iridium nanoparticles supported on carbon nanotubes [47] and $\mathrm{Ru} / \mathrm{Mg}$-LaO-mixed oxide [48] have been proposed as selective hydrogenation catalysts of levulinic acid to GVL.

p0220 Heterogeneous catalysis have been employed for the conversion of well-defined reactants aiming a high selectivity for one given chemical. In the field of biomass upgrading, heterogeneous catalysis has been pushed further to its potential. Three examples are worth mentioning as they intend to convert raw biomass and lignocelluloses into intermediates or marketable products.

p0225 The concept of lignin-first biorefining of lignocelluloses using a supported ruthenium catalyst in the presence of hydrogen has been reported in 2015 [49,50] and is being taken up by many other researchers $[51,52]$. . By using an appropriate solvent, like methanol, lignocellulose can be solvolyzed and hydrogenolyzed in one step into valuable carbohydrate pulp and liquid lignin oil. The lignin oil is composed of monomeric phenolic compounds next to some phenolic oligomers. This unconventional deconstruction of lignocellulose, lignin is simultaneously detached from the polysaccharide fibers, depolymerized and passivated by reductive conversion in the presence of a heterogeneous catalyst and hydrogen.

p0230 Another direct lignocelluloses catalytic conversion process is that developed by Gas Technology Institute, $\mathrm{IH}^{2}$ being an integrated hydropyrolysis of raw biomass in a tworeactor process [53]. Whereas pyrolysis of biomass results in very oxygenated compounds $(>30 \mathrm{wt} \%$ resulting in low $\mathrm{pH})$ next to significant amounts of soluble water $(\sim 20 \mathrm{wt} \%)$, requiring complex post-treatment $[54,55]$, the $\mathrm{IH}^{2}$ process can directly convert biomass to hydrocarbon transportation fuels through the use of hydropyrolysis or integrated hydropyrolysis plus hydroconversion. The first catalytic step of hydropyrolysis is carried out in a fast fluidized bed under 14-35bar of hydrogen pressure with an effective deoxygenation catalyst, similar to hydrotreatment catalysts (sulfide CoMo or NiMo catalysts, [56,57]). It directly produces fungible hydrocarbons with a TAN (Total Acid Number) of less than 1, which can either be directly fed to a refinery for coprocessing or polished in an integrated hydroconversion reactor to produce gasoline and diesel with less than $1 \%$ oxygen.

Carlson et al. recognized that pyrolysis and catalytic conversion can be done in the same reactor vessel which was the basis of the startup company, Anellotech [58]. The catalytic fast pyrolysis (CFP) process directly converts solid biomass to gasoline-range aromatics rich in BTX: benzene, toluene, and xylenes. CFP involves the rapid heating of biomass $\left(500^{\circ} \mathrm{C} / \mathrm{s}\right)$ in an inert atmosphere to intermediate temperatures $\left(400-600^{\circ} \mathrm{C}\right)$ in the presence of zeolite catalysts. In addition to aromatics, some valuable light olefins, such as ethylene and propylene, are produced. The understanding is that the biomass pyrolyses into furan-type intermediates, small enough to enter in the zeolite pores, where they are converted into aromatics and light olefins. The oxygen in the biomass is expelled as carbonoxides and water.

\section{CONCLUSIONS}

In this chapter, R\&D landscape on the cata- p0240 lytic upgrading of biomass over the last two decades is monitored by data-mining. More 
than 14 thousand patent and nonpatent literature documents, covered within the boundaries of the determined technology scope and published between 1998 and 2017, were retrieved from Scopus and DWPI then multidimensionally analyzed using Intellixir by the experts who cross-functionally work in catalysis, renewable biomass energy, intellectual property, and technology intelligence. The continuous growth in the number of PL and NPL records over the last two decades explicitly demonstrates the increase of the global attention on the catalytic conversion of renewable resources. The various types of proposed solid catalysts indicate the importance of the heterogeneous catalysis on the biomass upgrading. The number and growth of PL and NPL documents is very similar, reflecting that both the academic community and the industrial potential developers have similar interests.

Q15 p0245 Green and red cells, respectively, illustrate whether the numeric value is above the average or below the average value of the cells of columns, which report compound annual growth rate (CAGR) between 1998-2007, 2008-2017, and 1998-2017; the percentage of PL documents; and the cumulative number of PL and NPL of the top 25 biomass derived chemicals.

\section{st0045 Acknowledgments}

p0250 This work received the support of the ENSCM (Ecole Nationale Supérieure de Chimie de Montpellier) and of SINCHEM (Sustainable INdustrial CHEMistry), a joint doctorate programme selected under the Erasmus Mundus Action 1 Programme (FPA 2013-0037).

\section{References}

[1] http://www.intellixir.com/ (accessed 20.11.17).

[2] World Intellectual Property Indicators, World Intellectual Property Organization, 2016.

[3] World Intellectual Property Indicators, World Intellectual Property Organization, 2017.

[4] https://www.elsevier.com/solutions/scopus (accessed 01.12.17).
[5] https://www.elsevier.com/_data/assets/pdf_file/ 0007/69451/0597-Scopus-Content-Coverage-GuideUS-LETTER-v4-HI-singles-no-ticks.pdf (accessed 01. 12.17).

[6] https://clarivate.com/products/dwpi-reference-center/ dwpi-coverage/.

[7] http://www.epo.org/service-support/glossary.html\#p (accessed 20.11.17).

[8] https://data.worldbank.org (accessed 01.12.17).

[9] https://www.uspto.gov/web/offices/pac/mpep/s1801. html.

[10] http://www.renewableenergyworld.com/articles/2009/ 12 /brazils-wind-power-auction-spurs-more-cleanenergy-development.html.

[11] T. Werpy, G. Petersen, Top Value Added Chemicals from Biomass Volume I-Results of Screening for Potential Candidates from Sugars and Synthesis Gas Energy Efficiency and Renewable Energy, Pacific Northwest National Laboratory and National Renewable Energy Laboratory, 2004.

[12] J.J. Bozell, G.R. Petersen, Technology development for the production of biobased products from biorefinery carbohydrates. The US Department of Energy's "Top 10" revisited, Green Chem. 12 (2010) 539-554.

[13] M. Ohara, A. Takagaki, S. Nishimura, K. Ebitani, Syntheses of 5-hydroxymethylfurfural and levoglucosan by selective dehydration of glucose using solid acid and base catalysts, Appl. Catal. Gen. 383 (2010) 149-155.

[14] L. Hu, X. Tang, J. Xu, Z. Wu, L. Lin, S. Liu, Selective transformation of 5-hydroxymethylfurfural into the liquid fuel 2,5-dimethylfuran over carbon-supported ruthenium, Ind. Eng. Chem. Res. 53 (2014) 3056-3064.

[15] I. Jiménez-Morales, M. Moreno-Recio, J. SantamaríaGonzález, P. Maireles-Torres, A. Jiménez-López, Mesoporous tantalum oxide as catalyst for dehydration of glucose to 5-hydroxymethylfurfural, Appl. Catal. Environ. 154 (2014) 190-196.

[16] V.V. Ordomsky, J. Van Der Schaaf, J.C. Schouten, T.A. Nijhuis, Glucose dehydration to 5-hydroxymethylfurfural in a biphasic system over solid acid foams, ChemSusChem 6 (2013) 1697-1707.

[17] I. Jiménez-Morales, J. Santamaría-González, A. JiménezLópez, P. Maireles-Torres, Glucose dehydration to 5-hydroxymethylfurfural on zirconium containing mesoporous MCM-41 silica catalysts, Fuel 118 (2014) 265-271.

[18] M. Moreno-Recio, J. Santamaría-González, P. MairelesTorres, Brönsted and Lewis acid ZSM-5 zeolites for the catalytic dehydration of glucose into 5-hydroxymethylfurfural, Chem. Eng. J. 303 (2016) 22-30.

[19] C. Yue, M.S. Rigutto, E.J.M. Hensen, Glucose dehydration to 5-hydroxymethylfurfural by a combination of a basic zirconosilicate and a solid acid, Catal. Lett. 144 (2014) 2121-2128 
[20] F.S. Asghari, H. Yoshida, Dehydration of fructose to 5-hydroxymethylfurfural in sub-critical water over heterogeneous zirconium phosphate catalysts, Carbohydr. Res. 341 (2006) 2379-2387.

[21] Y. Zhang, V. Degirmenci, C. Li, E.J.M. Hensen, Phosphotungstic acid encapsulated in metal-organic framework as catalysts for carbohydrate dehydration to 5-hydroxymethylfurfural, ChemSusChem 4 (2011) 59-64.

[22] Y. Zhang, J. Wang, J. Ren, X. Liu, X. Li, Y. Xia, G.L. Y, Y. Wang, Mesoporous niobium phosphate: an excellent solid acid for the dehydration of fructose to 5-hydroxymethylfurfural in water, Cat. Sci. Technol. 2 (2012) 2485-2491.

[23] J.B. Joo, A. Vu, Q. Zhang, M. Dahl, M. Gu, F. Zaera, Y. Yin, A sulfated $\mathrm{ZrO}_{2}$ hollow nanostructure as an acid catalyst in the dehydration of fructose to 5-hydroxymethylfurfural, ChemSusChem 6 (2013) 2001-2008.

[24] X. Yi, I. Delidovich, Z. Sun, S. Wang, X. Wang, R. Palkovits, A heteropoly acid ionic crystal containing $\mathrm{Cr}$ as an active catalyst for dehydration of monosaccharides to produce 5-HMF in water, Cat. Sci. Technol. 5 (2015) 2496-2502.

[25] A. Villa, M. Schiavoni, P.F. Fulvio, S.M. Mahurin, S. Dai, R.T. Mayes, G.M. Veith, L. Prati, Phosphorylated mesoporous carbon as effective catalyst for the selective fructose dehydration to HMF, J. Energy Chem. 22 (2013) 305-311.

[26] A. Villa, M. Schiavoni, S. Campisi, G.M. Veith, L. Prati, $\mathrm{Pd}$-modified $\mathrm{Au}$ on carbon as an effective and durable catalyst for the direct oxidation of HMF to 2,5furandicarboxylic acid, ChemSusChem 6 (2013) 609-612.

[27] X. Wan, C. Zhou, J. Chen, W. Deng, Q. Zhang, Y. Yang, Y. Wang, Base-free aerobic oxidation of 5hydroxymethyl-furfural to 2,5-furandicarboxylic acid in water catalyzed by functionalized carbon nanotubesupported au-pd alloy nanoparticles, ACS Catal. 4 (2014) 2175-2185.

[28] O. Casanova, S. Iborra, A. Corma, Biomass into chemicals: aerobic oxidation of 5-hydroxymethyl-2-furfural into 2,5-furandicarboxylic acid with gold nanoparticle catalysts, ChemSusChem 2 (2009) 1138-1144.

[29] W. Niu, D. Wang, G. Yang, J. Sun, M. Wu, Y. Yoneyama, Y.N. Tsubaki, Pt nanoparticles loaded on reduced graphene oxide as an effective catalyst for the direct oxidation of 5-hydroxymethylfurfural (HMF) to produce 2,5-furandicarboxylic acid (FDCA) under mild conditions, Bull. Chem. Soc. Jpn. 87 (2014) 1124-1129.

[30] R. Sahu, P.L. Dhepe, Synthesis of 2,5-furandicarboxylic acid by the aerobic oxidation of 5-hydroxymethyl furfural over supported metal catalysts, React. Kinet. Mech. Catal. 112 (2014) 173-187.
[31] D.K. Mishra, H.J. Lee, J. Kim, H.-S. Lee, J.K. Cho, Y.W. Suh, Y. Yi, J.K. Kim, $\mathrm{MnCo}_{2} \mathrm{O}_{4}$ spinel supported ruthenium catalyst for air-oxidation of HMF to FDCA under aqueous phase and base-free conditions. Green Chem. 19 (2017) 1619-1623, https://doi.org/10.1039/ C7GC00027H.

[32] S. Wang, Z. Zhang, B. Liu, Catalytic conversion of fructose and 5-hydroxymethylfurfural into 2,5furandicarboxylic acid over a recyclable $\mathrm{Fe}_{3} \mathrm{O}_{4}-\mathrm{CoO}_{x}$ magnetite nanocatalyst, ACS Sustain. Chem. Eng. (3) (2015) 406-412.

[33] X. Han, C. Li, X. Liu, Q. Xia, Y. Wang, Selective oxidation of 5-hydroxymethylfurfural to 2,5-furandicarboxylic acid over $\mathrm{MnO}_{x}-\mathrm{CeO}_{2}$ composite catalysts, Green Chem. 19 (2017) 996-1004.

[34] E. Hayashi, T. Komanoya, K. Kamata, M. Hara, Heterogeneously-catalyzed aerobic oxidation of 5-hydroxymethylfurfural to 2,5-furandicarboxylic acid with $\mathrm{MnO}_{2}$, ChemSusChem 10 (2017) 654-658.

[35] Q. Liu, F. Yang, H. Yin, Y. Du, Conversion of saccharides into levulinic acid and 5-hydroxymethylfurfural over $\mathrm{WO}_{3}-\mathrm{Ta}_{2} \mathrm{O}_{5}$ catalysts, RSC Adv. 6 (2016) 49760-49763.

[36] C. Fang, Y. Liu, W. Wu, H. Li, Z. Wang, W. Zhao, T. Yang, S. Yang, One pot cascade conversion of bio-based furfural to Levulinic acid with Cu-doped niobium phosphate catalysts. Waste Biomass Valor (2017), https://doi.org/10.1007/s12649-017-0131-7.

[37] D.R. Fernandes, A.S. DR, E.F. Rocha, C.J.A. Mai, V. Mota, Teixeira Da Silva. Levulinic acid esterification with ethanol to ethyl levulinate production over solid acid catalysts, Appl. Catal. Gen. 425-416 (2012) 199-204.

[38] D. Unlu, O. Ilgen, N.D. Hilmioglu, Biodiesel additive ethyl levulinate synthesis by catalytic membrane: $\mathrm{SO}_{4}^{-2} / \mathrm{ZrO}_{2}$ loaded hydroxyethyl cellulose, Chem. Eng. J. 302 (2016) 260-268.

[39] N.A.S. Ramli, D. Sivasubramaniam, N.A.S. Amin, Esterification of levulinic acid using $\mathrm{ZrO}_{2}$-supported phosphotungstic acid catalyst for ethyl levulinate production, Bioenergy Res. 10 (2017) 1105-1116.

[40] A.H. Valekar, K.-H. Cho, S.K. Chitale, D.-Y. Hong, G.-Y. Cha, U.-H. Lee, D.W. Hwang, C. Serre, J.-S. Chang, Y.K. Hwang, Catalytic transfer hydrogenation of ethyl levulinate to $\gamma$-valerolactone over zirconium-based metal-organic frameworks, Green Chem. 18 (2016) 4542-4552.

[41] A.M. Raspoli Galletti, C. Antonett, V. De Luise, M. Martinelli, A sustainable process for the production of $\gamma$-valerolactone by hydrogenation of biomassderived levulinic acid, Green Chem. 14 (2012) 688-694.

[42] D.M. Alonso, J.M.R. Gallo, M.A. Mellmer, S.G. Wettstein, J.A. Dumesic, Direct conversion of cellulose to levulinic acid and gamma-valerolactone using solid acid catalysts, Cat. Sci. Technol. 3 (2013) 927-931. 
[43] P.P. Upare, J.M. Lee, D.W. Hwang, S.B. Halligudi, Y.K. Hwang, J.S. Chang, Selective hydrogenation of levulinic acid to $\gamma$-valerolactone over carbon-supported noble metal catalysts, J. Ind. Eng. Chem. 17 (2011) 287-292.

[44] L. Deng, Y. Zhao, J. Li, Y. Fu, B. Liao, Q.X. Guo, Conversion of levulinic acid and formic acid into $\gamma$-valerolactone over heterogeneous catalysts, ChemSusChem 3 (2010) $1172-1175$.

[45] V. Mohan, V. Venkateshwarlu, C.V. Pramod, B.D. Raju, K.S.R. Rao, Vapour phase hydrocyclisation of levulinic acid to $\gamma$-valerolactone over supported Ni catalysts, Cat. Sci. Technol. 4 (2014) 1253-1259.

[46] S.G. Wettstein, J.Q. Bond, D.M. Alonso, H.N. Pham, A.K. Datye, J.A. Dumesic, RuSn bimetallic catalysts for selective hydrogenation of levulinic acid to $\gamma$-valerolactone, Appl. Catal. Environ. 117-118 (2012) 321-329.

[47] X. Du, Y. Liu, J. Wang, Y. Cao, K. Fan, Catalytic conversion of biomass-derived levulinic acid into $\gamma$-valerolactone using iridium nanoparticles supported on carbon nanotubes, Chin. J. Catal. 34 (2013) 993-1001.

[48] V. Swarna Jaya, M. Sudhakar, S. Naveen Kumar, A. Venugopal, Selective hydrogenation of levulinic acid to $\gamma$-valerolactone over a $\mathrm{Ru} / \mathrm{Mg}-\mathrm{LaO}$ catalyst, $\mathrm{RSC}$ Adv. 5 (2015) 9044-9049.

[49] W. Schutyser, S. Van den Bosch, T. Renders, T. De Boe, S.-F. Koelewijn, A. Dewaele, T. Ennaert, O. Verkinderen, B. Goderis, C.M. Courtin, B.F. Sels, Influence of biobased solvents on the catalytic reductive fractionation of birch wood, Green Chem. 17 (2015) 5035-5045.

[50] S. Van den Bosch, W. Schutyser, R. Vanholme, T. Driessen, S.-F. Koelewijn, T. Renders, B. De Meester, W.J.J. Huijgen, W. Dehaen, C.M. Courtin, B. Lagrain, W. Boerjan, B.F. Sels, Reductive lignocellulose fractionation into soluble lignin-derived phenolic monomers and dimers and processable carbohydrate pulps, Energ. Environ. Sci. 8 (2015) 1748-1763.
[51] R. Rinaldi, R. Jastrzebski, M.T. Cloug, J. Ralph, M. Kennema, P.C.A. Bruijnincx, B.M. Weckhuysen, Paving the way for lignin valorisation: recent advances in bioengineering, biorefining and catalysis, Angew. Chem. Int. Ed. 55 (2016) 8164-8215.

[52] R. Rinaldi, A tandem for lignin-first biorefinery, Joule 1 (2017) 427-428.

[53] T.L. Marker, L.G. Felix, M.B. Linck, M.J. Roberts, Integrated hydropyrolysis and hydroconversion (IH2) for the direct production of gasoline and diesel fuels or blending components from biomass, part 1: proof of principle testing, Environ. Prog. Sustain. Energy 31 (2012) 191-199.

[54] A.H. Zacher, M.V. Olarte, D.M. Santosa, D.C. Elliott, S.B. Jones, A review and perspective of recent bio-oil hydrotreating research, Green Chem. 16 (2014) 491-515.

[55] A.R.K. Gollakota, M. Reddy, M.D. Subramanyam, N. Kishore, A review on the upgradation techniques of pyrolysis oil, Renew. Sustain. Energy Rev. 58 (2016) 1543-1568.

[56] T.L. Marker, L.G. Felix, M.B. Linck, M.J. Roberts, Bubbling bed catalytic hydropyrolysis process utilizing larger catalyst particles and smaller biomass particles featuring an anti-slugging reactor, US 2012/0260563 A1 (2012).

[57] V.N. Urade, L.N. Chilkoor Soundararajan, S. Gopal, M.R. Panchagnula, A.A. Del Paggio, Conversion of solid biomass into a liquid hydrocarbon material, WO/2016/001163 A1 (2016).

[58] J. Jae, G.A. Tompsett, Y.-C. Lin, T.R. Carlson, J. Shen, T. Zhang, T.B. Yang, C.E. Wyman, W.C. Conner, G. W. Huber, Depolymerization of lignocellulosic biomass to fuel precursors: maximizing carbon efficiency by combining hydrolysis with pyrolysis, Energ. Environ. Sci. 3 (2010) 358-365. 


\title{
Non-Print Items
}

\begin{abstract}
For the last decade, the scientific community and industrial developers have been searching for improved methods to convert biomass into valuable products in order to respond to enhanced sustainability considerations. In this development, catalysts play an essential role at the core of the many technological routes to convert complex biomass into fuels or chemicals, which can be used in our daily lives. This chapter reports on the evolution of catalytic conversion of biomass by exploring databases on scientific literature and on patents retrieved from Scopus and DWPI. The trend analysis of more than 14,000 patent and nonpatent documents on renewable biological feedstock conversion by catalytic route has been carried out by using Intellixir, a statistical tool to analyze a large number of data for scientific intelligence.

The scope of this chapter is to not only display a comprehensive study on patent and nonpatent literature in the catalytic upgrading (value creation) of biomass, but to increase the awareness in the use of patent literature as a tool to reach the rich and open-source treasure of knowledge in various technological fields.
\end{abstract}

Keywords: Patent and nonpatent literature, Renewable feedstock, Biomass conversion, Heterogeneous catalysis, Intellectual property, Metadata, Data-mining 